\title{
Stanisław Książek
}

\section{Granice i podział diecezji wrocławskiej na komisariaty i dekanaty w latach 1914-1945}

Prawo Kanoniczne : kwartalnik prawno-historyczny 19/3-4, 123-152

1976

Artykuł został zdigitalizowany i opracowany do udostępnienia w internecie przez Muzeum Historii Polski w ramach prac podejmowanych na rzecz zapewnienia otwartego, powszechnego i trwałego dostępu do polskiego dorobku naukowego i kulturalnego. Artykuł jest umieszczony w kolekcji cyfrowej bazhum.muzhp.pl, gromadzącej zawartość polskich czasopism humanistycznych i społecznych.

Tekst jest udostępniony do wykorzystania w ramach dozwolonego użytku. 
Ks. STANISEAW KSIAZŻEK

\section{GRANICE I PODZIAE DIECEZJI WROCEAWSKIEJ NA KOMISARIATY I DEKANATY W LATACH $1914-1945$}

Treść: Wstęp, I. Granice diecezji wrocławskiej, II. Podzial terytorium na część: pruską, czeską i delegaturę berlińską, III. Wewnętrzny podzial poszczególnych części diecezji. Zakończenie.

\section{Wstęp}

Ludzki sposób realizacji dzieła zbawienia wymaga, aby należący do świętej społeczności Kościoła obak Najwyższego Pasterza posiadali własnych pasterzy, którzy dbaliby na saiśle określonym terenie o ich duchawe dobro. To stanawi rację administracyjnego padziału terytorium Kościoła na diecezje i parafie.

Granice diecez.ji wrocłarwskiej w latach 1914-1945 uległy poważnym zmianom. $\mathrm{Z}$ wschodniej i północnej części terytorium podległego biskupowi wroclawsikiemu wydzielone zostały dwie diecezje: katowicka $i$ berlińska, któne posiadają duże znaczenie w życiu Kościoła. Wrocław natamiast wyniesiony został do godnosei metropolii. Zmiany granic diecezji należące do kompetencji Stolicy Apostolskiej wpłynęly na wewnętrzną reorganizację, którą przeprowadzil w czasie swych rządów w diecezji wrocławskiej kardynał Adolf Bertram. Praca niniejsza daje zainteresowanemu dziejami diecezji wrocławskiej i osobą kardynała Bertrama odpowiedź na zasadinicze pytania:

a. jakie terytorium padlegało biskupiej jurysdykcji kardynała Bertrama w latach 1914-1945,

b. jak ukształtowane były wewnętrzne części diecezji "właściwej” i delegatury berliniskiej.

We Wrockawiu stworzono specyficzne instytucje podziału terytorialnego. $\mathrm{Z}$ tej racji obok terytorialnego zasięgu poszczególnych jednostek, w agólnym ujęciu uwzględniono prawa i obowiązki ich rządców. W języku niemieckim pozostawionı nazwy tych miejscowości, które nawet przez krótki czas mie należały w ostatnim stuleciu do Polski. Dla określenia nazw polskich wykorzyistano: Rospond S., Skorowidz ustalonych nazw miejscowości na Ziemiach Odzyskanych i Rospond S., Slownilk nazw geograficznych Polski Zachodniej i Północnej.

Granicom diecezji wrocławskiej w latach $1914-1945$ poświęcili nieco uwagi: Biskup Urban Wincenty, Zarys dziejów diecezji wroclawskiej i Rogalski Aleksander, Kościół katolicki na Sląsku. Nie zajęli się tą kwestią niemieccy historycy. 


\section{Granice diecezji wroclawskiej}

Diecezja wroclawska łączy się nierozdzielnie ze Sląskiem położonym w górnym i środkowym dorzeczu Odry. Pierwsza organizacja kościelna na tym terenie powstała w roku $1000 \mathrm{w}$ czasie zjazdu Bolesława Chrobrego z cesarzem Ottonem.III u grobu św. Wojciecha w Gnieźnie. ${ }^{1}$ Utworzenie metropolii gnieźnieńskiej $z$ biskupstwem krakowskim, wroclawskim i kołobrzeskim jako sufraganiami bylo wynikiem starań Bolesława Chrobrego, podjętych w Stolicy Apostolskiej zaraz po śmierci św. Wojciecha. Nowa Diecezja sąsiadowała $z$ biskupstwem w Poznaniu powstałym w 966 roku, $z$ metropoliaz w Magdeburgu stworzoną $w 968$ roku i biskupstwem w Prađze założonym w 973 roku. ${ }^{2}$

Po śmierci Mieszka II (1025-1034) jak w wielu krajach masowo newracanych powstala w Polsce gwałtowna reakcja pogariska. Zrujnowana została cała organizacja kościelna. Zniszczono stolice biskupie, świątynie i klasztory. $\mathbf{Z}$ tego zamętu religijnego, politycznego i społecznego skorzystał książe czeski Bratysław, który najechał na Polskę docierając aż do Gniezna. ${ }^{3}$ Sląsk przez 12 lat pozostawał pod panowaniem czeskim. ${ }^{4}$ Najmniej ucierpiał Kraków, toteż stal się faktycznie stolica państwa. ${ }^{5}$ Biskup krakowski Aron owocnie współpracował z Kazimierzem Odnowicielem na polu odnowienia organizacji Kościoła. Oparcie się na niedawnej przeszłości powiodło się całkowicie. Syn Odnowiciela Bolesław Szczodry nawiązał biiższe stosunki z papieżem Grzegorzem VII. Legaci Stolicy Apostolskiej w 1075 roku ostatecznie zorganizowali polską prowincję kościelną. W skład metropolii gnieźnieńskiej weszło 5 diecezji: gnieźnieńska, poznańska, wnocławska, krakowska i płocka. ${ }^{\circ}$

Nie mamy papieskiego dokumentu określającego zasięg terytoriainy biskupstwa wrocławskiego w 1000, czy 1075 roku. Można jednak przypuszczać, że pierwotne granice nie odbiegały zasadniczo od tych, które można wyprowadzić na podstawie bulli protekcyjnej papieża Hadriana IV z dnia 23 kwietnia 1155 roku i Innocentego IV z dnia 9 sierpnia 1245 roku. ${ }^{7}$ Pierwsza wylicza 15 grodów stanowiących ośrodki paístwowej administracji. Opasywały one terytorium diecezji od południa, południowego zachođu, zachodu i północy. Nie została zakreślona granica od wschodu, bo najprawdopodobniej biskup krakowski nie przejawiał

1 Kronika Thietmara, tłum. N. Z. Jedlicki, Poznań 1953, IV, 45; - Silnicki T. Dzieje $i$ ustrój Kościola katolickiego na Slasku do końca w. XIV, Warszawa 1953, s. 9; - Urban W., Zarys dziejów diecezji wroctawskiej, Wrocław 1962, s. 18; - Rogals ki A., Kościót katolicki na Slqsku, Warszawa 1955, s. 11.

${ }^{2} \mathrm{U}$ r ba n W., Zarys dziejów..., dz. c., s. 7.

3 U m iń s k i J., Historia Kościoła, t. 1, Opole 1959, s. 307.

4 R o galski A., dz. c., s. 11.

5 Sulowski Z., Początki Kościola polskiego, W: Kościół w Polsce, t. 1, Kraków 1966, s. 90.

6 Tamże, s. 93. 
tendencji uszczuplania ziem Kosciola wroclawskiego. ${ }^{8}$ Druga podaje liczbę 22 grodów kasztelańskich rozmieszczonych na terenie diecezji. Biskupstwo wroclawskie graniczyło wtedy z biskupstwem: krakowskim, poznańskim, lubuskim, miśnieńskim, praskim i olomunieckim. Z tymi biskupstwami powstały $\mathrm{w}$ ciągu wiekbow odchylenia graniczne. ${ }^{9}$

$\mathrm{Na}$ poludniowej linii granicznej zaznaczają się następujące przesunięcia: Ziemia Opawska (Opawa, Karniów, Głubczyce) należąca w XII wieku do diecezji wrocławskiej przyłączona do Moraw weszła w skład diecezji ołomunieckiej i mimo politycznych zmian terenowych pozostała w niej do 1945 roku. Ziemia Kłodzka zwana Hrabstwem Klodzkim należąca do Czech stanowiła część diecezji praskiej i pozostała w niej do 1945 roku, chociaż złączyła się z księstwami śląskimi. Mieroszów i okoliczne wioski: Unisław Śląski, Rybnica Leśna i Kamionka należały w noku 1217 do Czech. Z diecezją wrocławską zostały złączone w 1654 roku. ${ }^{10}$ Chelmsko Sląskie należące do Czech dnia 23 sierpnlia 1289 roku addał król Wacław II Bolkowi II księciu świdnicko-lwóweckiemu, przez co przyłączone zostało do Sląska i diecezji wrocławskiej. ${ }^{11}$ W roku 1344 stworzono prowincję kościelną w Pradze. Usiłowano do niej włączyć jeśli nie w całości, to przynajmniej w części diecezję wrocławską. Sprawa ta spotkała się ze sprzeciwem ze strony polskiej. Cesarz Karol przyrzekł królowi Kazimierzowi Wielkiemu w roku 1360, że nie ponowi swych starań. ${ }^{\mathbf{2}}$

Od zachodu diecezja wrocławska graniczyła $\mathrm{z}$ diecezją miśnieńską, do której ad 1247 roku należał Mirsk. W roku 1337 przyłączony został do księstwa jaworskiego, ale biskup wrockawski mógł nad nim .roztoczyć swą jurysdykcję dopiero w 1654 roku. Wsikutek zalewu protestantyzmu biskupstwo miśnieńskie przestało istnieć. Parafie diecezji miśnieńskiej wchodzące w skład archiprezbiteratu (dekanatu) żarskiego i częściowo spremberskiego, państwowo zależne od księcia żagańskiego, weszły w skład biskupstwa wrocławskiego w roku 1668.

Wysunięty na pólnoc Sulechów należał do diecezji wrocławskiej, a Swiebodzin $z$ okolicami do diecezji poznańskiej. $\mathrm{Z}$ chwilą gdy powiat świebodziński przeszedł pod władzę Habsburgów, został wcielony do diecezji wrocławskiej. ${ }^{13}$ Parafie Siedlęcin, Zamysłów i Konradowno złączone od 1738 roku z archiprezbiteratem w Górze Sląskiej, a potem w Sławie, po zawarciu pokoju w Tylży 1807 roku weszły w skład Kslięstwa Warszawskiego if poddane zostały jurysdykcji bisikupa poznańskiego. Ostrzeszów i Kępno mimo więzów łączących je z Polską po-

7 U r ban W., Zarys dziejów..., dz. c., s. 8.

${ }^{8} \mathrm{~S}$ il $\mathrm{ln}$ icki T., dz. c., s. 44.

${ }^{9} \mathrm{Urban} \mathrm{W.,} \mathrm{Zarys} \mathrm{dziejów...,} \mathrm{dz.} \mathrm{c.,} \mathrm{s.} 8$.

${ }^{10}$ Tamże, s. 9 ns.

$11 \mathrm{Kirsch}$ F., Schömberg, W: Heimatbuch des Kreises Landeshut, t. 2, Landeshut 1929, s. 604.

12 Silnicki T., dz. c., s. 262 ns.

1s Rogals ki A., dz. c., s. 9. 
zastawały $\mathrm{w}$ diecezji wrocławskiej. W roku 1787 powstał dla nich oddzielny oficjalat. Przez 11 lat do diecezji wrackawskiej należało 48 parafii $z$ archiprezbiteratów: Częstochowa, Siewierz i Pilica, które po trzecim rozbiorze Polsiki wcielone do Prus stanowiły tzw. Nowy Sląsk. W 1811 roku biskup wroclawski Hohenlohe odstąpil jurysdykcję na tym terenie biskupowi krakowskiemu, a w zamian za to otrzymal w zarząd dekanaty: bytomski i pszczyński nakeżące do Krakawa. ${ }^{14}$

Doniosłe znaczenie dla granic diecezji wrocławskiej miała bulla De salute animarum $\mathrm{z}$ dnia 16 lipca 1821 roku. Ustaliła granice, które przetrwały do 1922 roku. Papiez Pius VII wylączył z diecezji wroclawskiej dekanaty: Ostrzeszów i Kępno przydzielając je do archidiecezji poznańskiej. Dekanat pszczyński i bytomski włączył do diecezji wroclawskiej. Odnośnie granicy poludniowej i parafii na terenie Austrii nie dokonano żadnych zmian. $Z$ terytorium Eużyc wcielono do diecezji wrocławskiej 21 parafii, z których część podlegała niezależnemu klaszticrowi w Neuzelle, a kilka pozostawalo pad administracją dziekana kolegiaty kościoła św. Piotra w Budziszynie. Wladzy biskupa wrocławskiego poddane zostało terytorium Wikariatu Apostolskiego Misji Północnych ${ }^{15}$ obejmujące marchię brandenburską i pomorską. Ziemie te ze wziględu na specjalny charakter prawny nazwano delegaturą berlinską. Granice między delegaturą berlińską a diecezją chelmińską ustalono $w$ latach 1861 i 1899 , ponileważ bulla mając na uwadze misyjny charakter delegatury, nie podała jej wschodniej granicy. ${ }^{16}$

Terytorium diecezji wroclawskiej w XIV wieku posiadało $36.400 \mathrm{kj}$ lometrów kwadratowych i około 407.000 mieszkańców. ${ }^{17} \mathrm{~W}$ XVII wieku diecezja liczyła około 37.300 kilometrów kwadratowych, ${ }^{18}$ a w chwili objęcia pasterskich rządów przez kardynała Bertrama zajmowała prawie $1 / 3$ państwa pruskiego. ${ }^{19}$

Od pómocy zasięg jurysdykcji biskupa wrocławskiego wyznaczała naturalna granica morza Bałtyckiego. Wychodzila $z$ okolicy ujścia rzekj Reknitz, obejmowała wyspe Rugię i biegła aź do jeziora Łebsikiego.

Gramice wschodnią na północy wyznaczała rzeka Eseba. Na wysokości Lęborka odrywała się odrzeki obejmując zachodnie granice powiatu bytowskiego należącego $w 1914$ roku do diecezji chelmińskiej. Następnie po granicy diecezji poznańskiej łukiem skierowanym na zachód w końcowym biegu rzeki Drawy zetknęha się z Natecią. Stąd następnym lukiem zmierzała na zachód pozostawiając po stronie diecezji wrocław-

14 U r ba n W., Zarys dziejów..., dz. c., s. 10 ns.

15 Bulla De salute animarum, alinea 32, W: Papiestwo wobec sprawy polskiej $w$ latach 1772-1864, Wybór źródel, opr. B e i ers d orf $O$, Wroclaw 1960, s. 292.

16 Urban W., Zarys dziejów..., dz. c., s. 15.

17 S y mański J., Biskupstwa priskie w wiekach średnich. Organizacja i funkcje, W: Kościól w Polsce, t. 1, Kraków 1966, s. 180.

18 Litak S., Struktura $i$ funkcjonowanie parafii w Polsce, W: Kościól w Polsce, t. 2, Kraków 1969, s. 284.

19 Urban W., Zarys dziejów..., dz. c., s. 15. 
skiej miejscowości: Drezdenko, Gorzów Wielkopolski, Sulęcin, Swiebodzin, Sulechów, Sława Sląska, Krzepielów, Wilków Głogowski. Oparła się o Odrę, ale zaraz wzbiła się na północ i dość zębato zeszła na poludniowy wschód, by poza parafialnymi miejscowościami wrocławskiej diecezji: Siciny, Chróścina, Czernina, Wąsosz, Korzeńsko, Radziądz, Milicz, Cieszków, Kuźnica Czeszycka, Cieszyn, Międzybórz, Mąkoszyce, Bralin, Nowa Wies Książęca, Rychtal, Woskowice Małe i Włochy objąć powwiaty: Góra Sląska, Milicz, Syców, Namysłów oraz Kluczbork i zetknąć się W Kostowie koło Byczyny z rzeką Prosną, po której brzegu schodziła aż do Sternalic. Prawie w prostej linili biegła ku południowi do Bodzanowic, a następnie Liswartą do Boronowa i dalej wyraźnie na południe do Lubszy, Woźnik, Dąbrówki Wielkiej, przedmieściami Katowic i Mysłowic. Tu dluższy odcinek naturalnej granicy korytem Przemszy i Wisły do Czechowic. Wreszcie objela Bielsko i schodziła na południe między Zwardoniem a Koniakowem.

Stąd przyjmowała kierunek poludniowo-zachodni, by opasać powiat: Cieszyn, Friedek i Freistadt. Wzniosła się dość wyraźnie ku północy zachowując zachodnie nachylenie. Ujmowała miejscowości: Chałupki, Krzyżanowice, Tworków, Wojnowice, Krowiarki, Maciowakrze, Dziémarowy, Grudnie Wielką, Kazimierz i Sciborzyce Małe, pozostawiając na zewnątrz powiat Głubczyce i część powiatu Racibórz. ${ }^{20}$ Od Raclawic Sląskich $w$ niewielkim oddaleniu i prawie równolegle do rzeki Osoblogiej kierując się ku zachodowi, a od Jarnołtówka ostrym lukiem zmieniała kierunek by objąć część dawnego księstwa nyskiego z granicznymi parafiami: Zuckmantel, Olbersdorf, Heinzendorf, Hermannstadt, Einsiedel, Ober-Thomasdorf, Nieder-Thomasdorf, Lindewiese, Gurschdorf, Neu-Wilmsdorf oraz lokaliami Waldek i Krautenwalde. 21 Przedzierała się na północną stronę pasma górskiego, by od Białej Wody opuszczając Hrabstwo Kłodzkie zmierzać na pólnocny zachód do Zgorzelca. Przy tym obejmowała parafie i lokalie: Zloty Stok, Makolno, Laski, Ożary, Bardo Śląskie, Srebrna Góra, Budzow, Rudzica, Bielawa, Pieszyce, Rościszów, Walim, Głuszyca Gorna, Mieroszów, Chelmsko Sląskie, Okrzeszyn, Lubawka, Miszkowice, Karpacz, Szklarska Poręba, Czernina Zdrój i Zawidów. ${ }^{22} \mathrm{~W}$ Zgorzelcu przecinała Nysę Eużycką i przez terytorium należące przed reformacją do diecezji miśnieńskiej wznosiła się łukiem na pólnoc do ujścia rzeki Reknitz obejmując przy tym rzadko rozmieszczone w Eużycach, Brandenburgii i na Pomorzu parafie: Hoyerswerda, Senftenberg, Lübben, Brandenburg nad Havel i Wittenberge. ${ }^{23}$ To olbrzymie terytorium, $\mathrm{z}$ którym $\mathrm{w}$ ciągu wieków lączono

20 Mapa Polski, Przedsiębiorstwo Wydawnictw Kartograficznych, Warszawa 1959, skala $1: 500000$.

21 Atlas des Erzbistums Breslau (Preussischer Anteil), Breslau 1937, nr 518. 517, 497.

22 Mapa Polski, dz. c.

23 Schematismus des Bistums Breslau und seines Delegatur-Bezirks für das Jahr 1867, Breslau, s. 92, 146 ns.; -Handbuch des Bistums Breslau und seines Delegatur -Bezirks für das Jahr 1914, Breslau, s. 37, 57. 
nowe ziemie, w okresie rządów kardynała Bertrama przechodzilo różne koleje zmierzające do uformowania takiej diecezji, aby biskup mógł osobiście spełniać funkcje biskupie i kierować powierzoną społecznością.

Po zakończeniu pierwszej wojny światowej Polska odzyskała niepodległość. Układy polityczne wytyczyły granice państwowe. Z górnego Sląska przypadło Polsce 321.342 ha z 892.537 mieszkańcami, prawie w całości katolikami. ${ }^{24}$

Kardynał Bertram aczkolwiek niechętnie ustosunkowany wobec sprawy polskiej, ${ }^{25}$ widząc przychylność Stolicy Apostolskiej zmuszony był udzielić dziekanowi mikołowskiemu i równocześnie proboszczowi w Tychach księdzu Janowi Kapicy daleko idących uprawnień. ${ }^{26}$ Dekretem z dnia 21 października 1921 roku otrzymał ks. Kapica prawa i obowiązki wikariusza generalnego „w obszarze na Górnym Sląsku przypadającym do Państwa Polskiego." 27 W ten sposób powstała Książęco-Biskupia Delegatura dla polskiej części Górnego Sląska, która pod względem organizacji kościelnej byla instytucją prowizoryczną stojącą niżej od administracji apostolskiej, podlegającą prawnie biskupowi wrocławskiemu. Powszechne prawo kościelne nie zna podziału terytorium na delegatury czy administracje apostolskie. W kanonach $312-318$ K.P.K. jest określony urząd administratora apostolskiego dla zarządu diecezją kanonicznie erygowaną. Administratora ustanawia papież dla ważnych i szczególnych przyczyn. Praktyka papieska potwierza, że może być mianowany administrator dla części diecezji, która aktem prawnym nie została $z$ erygowanej diecezji wydzielona. Delegat Księcia-Biskupa był wybitnym kaznodzieją śląskim, był czlonkiem parlamentu pruskiego i doskonałym organizatorem, ale napotkał wiele trudności $\mathrm{z}$ racji braku funduszów i pomieszczeń. W takiej sytuacji prawnej i faktycznej nie mógł wiele zrobić. Przedstawił więc sprawę Warszawskiej Nuncjaturze Apostolskiej $\mathrm{w}$ specjalnym piśmie z dnia 26 października 1922 roku. Stolica Apostolska 7 listopada 1922 roku zamianowała dla tego terenu administratora apostolskiego $w$ osobie urodzonego na Górnym Sląsku w parafii Mysłowice księdza Augusta Hlonda prowincjała salezjanów. ${ }^{28}$

${ }^{24}$ Engelbert K., Adolf Kardinal Bertram Fürstbischof von Breslau (1914-1945), Archiv für schlesische Kirchengeschichte, t. 7, Hildesheim 1949 , s. 13.

${ }^{25} \mathrm{R} 0 \mathrm{~g}$ a $1 \mathrm{ski}$ A., dz. c., s. 127 ns.

26 Engelbert K., Geschichte des Breslauer Domkapitels in Rahmen der Diözesangeschichte vom Beginn des 19 Jahrhunderts bis zum Ende des Zweiten Weltkrieges, Hildesheim 1964, s. 178 ns.; - Engelbert K., Adolf Kardinal Bertram..., dz. c., s. 13 ns.; - S z ramek E., Ks. Jan Kapica, Życiorys a zarazem fragment z historii Górnego Sląska, Katowice 1931, s. 77.

27 Errichtung eines Fürstbischöflichen Delegaturamtes in OberschIesien, W: Verordnungen des Fürstbischöflichen General-Vikariat-Amtes zu Breslau, (skrót: Verordnungen...,) 14(1921), s. 129; - U r b a n W., Ostatni etap Kościola $w$ Polsce przed nowym tysiacleciem (1815-1965), Rzym 1966, s. 494.

${ }_{28}$ Constitutio Administratoris Apostolici pro Silesiae Superioris parte 
Na mocy tego aktu prawnego polska część Górnego Sląska została wyjęta $z$ pod władzy biskupa wrocławskiego. Polski Sląsk Cieszyński pozostał nadal w diecezji wrocławskiej. Kierował nim kardynał Bertram przez generalny wikariat w Cieszynie. ${ }^{29}$ Sprawa granic nowej diecezji nie została jeszcze definitywnie załatwiona. Czekano na wypracowanie całokształtu podziału terytorialnego Kościoła w Polsce. Podjął się tego zadania Episkopat Polski, który swiadomy był wielu anomalii powstałych podczas długiej niewoli. Na konferencji 18-19 marca i 7 lipca 1924 roku ustalono zasady, którymi należało się kierować przy tworzeniu nowych diecezji i rozgraniczaniu dawnych. Postanowiono uwzględnić na pierwszym miejscu potrzeby religijne i państwowe wiernych, nowe rozgraniczenie metropolii i diecezji proponować tylko tam, gdzie wymaga tego dobro życia katolickiego, usunąć granice powstałe wskutek zaborów, formować diecezje o liczbie wiernych od 500 tysięcy do miliona, a w miejscowościach gdzie ludność katolicka pomieszana jest $z$ akatolicką, zaplanować taką liczbę biskupstw, jaką posiadają akatolicy. Dla łatwiejszego dostępu do biskupa, na stolice diecezji wybierać miejscowość położoną centralnie, a na stolicę metropolii miejscowrość oddaloną od politycznych granic państwa. Wysunięto, by metropolia obejmowała swymi granicami ludność zbliżoną do siebie pod względem społeczno-religijnym. ${ }^{30}$

Postulaty powyższe w całej rozciągłości wykorzystano odnośnie terytorium Górnego Sląska wydzielonego z diecezji wrocławskiej, na którym mieszkała odpowiednia ilość wiernych złączona wspólnotą polityczną i religijną. Za umiejscowieniem stolicy biskupiej w Katowicach przemawiało nie tylko centralne polożenie miasta $w$ stosunku do terytorium, ale również perspektywy rozwoju jako ośrodka państwowej administracji. Sejm Sląski 19. 12. 1922 roku uchwalił dotację w sumie 20 milionów marek niemieckich na uruchomienie urzędów administracji apostolskiej, a dnia 6. 02. 1923 roku przyznano 40 milionow marek niemieckich jako miesięczną subwencję, którą wypłacano do końca 1923 roku. ${ }^{31}$ Bullą "Vixdum Poloniae" dnia 29 czerwca 1925 roku stworzono w Katowicach biskupstwo i włączono je jako sufraganię do metropolii krakowskiej. Za włączeniem Katowic do metropolii krakowskiej przemawiało nie tylko sąsiedztwo, ale również fakt historyczny przynależności części tych ziem do diecezji krakowskiej. Z diecezji wrocławskiej zostały wydzielone następujące dekanaty, parafie i miejscowości, które weszły w skład biskupstwa katowickiego: ${ }^{32}$

Polonica, dekret $z$ dn. 7.11.1922 r., W: Verordnungen..., 24(1922) s. 153; Urban W., Ostatni etap..., dz. c., s. 494.

${ }_{29} \mathrm{~J}$ a n i cki S., 10 lat przynależności Slaska do Rzeczypospolitej, Katowice 1932, s. 367; - Lon dzin J., Historja Generalnego Wikarjat $\iota$ $w$ Cieszynie, Cieszyn 1926, s. 75.

30 K u mor B., Granice metropolii i diecezjii polskich, Archiwa, Biblioteki i Muzea kościelne, t. 22(1971), s. 356.

$31 \mathrm{~J}$ a n i cki S., dz. c., s. 370 .

32 Real-Handbuch des Bistums Breslau, Breslau 1929, cz. 1, s. 133 ns. 
z Górnego Sląska:

dekanaty: Chorzów, Mikołów, Mysłowice, Pszczyna, Wodzisław Sląski, Tarnowskie Góry (z wyjątkiem części parafii Stare Repty), Żory;

parafie: z dekanatu Bytom: Godula, Lipiny, Nowy Bytom, Orzegów, część parafii Rozbark-Bytom;

z dekanatu Dębieńsko: Bełk, Dębieńsko, Gierałtowice, Knurów, Górna Wilcza (lokalia z parafii Pilchowice), Ornontowice, Przyszowice;

z dekanatu Gliwice: wschodnia część parafii Rudy Raciborskie;

z dekanatu Lubliniec: Boronow, Kochanowice, Koszęcin, Lubecko z wyjątkiem lokalii Zborowskie, Lubliniec, Lubsza, Olszyna, polowa parafii Pawonków, Sadów;

z dekanatu Pogrzebień: Brzezie (częściowo), Gorzyce, Lubomia, Lyski (częściowo), wschodnia częsć parafii Markowice, która pozostała przy Wrocławiu, Pogrzebień, Pstrążna, Raszczyce, Rogów;

z dekanatu Pyskowice: wschodnia część parafii Tworóg;

z dekanatu Twrorków: wschodnia częsć parafii Tworków;

z dekanatu Zabrze: Bielszowice, Bujaków, Kończyce, Pawłów, Ruda aż do dzielnicy Zabrze-Poręba;

z dawnej części Sląska austriackiego:

dekanaty: Bielsko, Skoczów, Strumień;

parafie: $\quad \mathrm{z}$ dekanatu Frysztat: Zebrzydowice;

z dekanatu Jabłonkbw: Istebna;

z dekanatu Cieszyn: Golesz6w, Leszna, Ogrodzona, Pogwizdów, Puńców, wschodnia część Cieszyna do Olzy, Ustroń.

Nowa granica diecezji rozpoczynała swój bieg od Liswarty na wysokości Zbonowskiego. Odbijała na zachód pozostawiając $w$ diecezji wroclawskiej parafie: Sieraków, Dobrodzień, Zawadzkie, Kielcza, stąd przechodziła łukiem na wschód granicami wschodnimi parafii: Tworóg, Zbrosławice, Bytom, Zabrze, Bojków, Żernica, Pilchowice, Rudy, Racibórz i prawie bez odchyleń korytem rzeki Odry i Olzy do styku $\mathrm{z}$ dawną granicą wschodnią.

Z Dolnego Sląska na mocy układów politycznych znalazła się w granicach Polski część porwiatu namysłowskiego i sycowskiego o powierzchni. 51.156 ha i 26.248 mieszkanców. Terytorium wyżej wymienione włączone zostało dnia 29 czerwca 1925 roku do archidiecezji gnieźnieńsko-poznańskiej. ${ }^{38}$ Diecezja wrochawska straciła:

z dekanatu Góra Sląska: część parafii Wạsosz i część parafii

Czernina;

z dekanatu Milicz: prawie całą parafię Cieszvn, część parafii Goszcz i część parafii Kuźnia Czeszycka;

${ }^{33}$ Enge l bert K., Adolf Kardinal Bertram..., dz. c., s. 14. 
z dekanatu Rychtal: parafię Krzyżowniki, Rychtal i część parafii Gluszyna;

z dekanatu Syców: parafię Bralin, Nowa Wieś Książęca, Marcinki-Mąkoszyce, Trębaczów, Turkowy, oraz częsć parafii Sycówi Międzybórz. ${ }^{34}$

Nowa granica na tym odcink przebiegała nieco na w'schód od Międzyborza, Sycowa, Głuszyny i Woskowic Małych.

Stosunki między Kościołem a Prusami regulowane były ponad sto lat zasadami zawartymi $w$ bulli „De salute animarum" $z$ dnia 16 lipca 1821 roku. Wiele $w$ tym czasie zmieniło się $w$ Prusach tak na plaszczyźnie kościelnej jak i na płaszczyźnie państwowej. Wymagało to nowego porozumienia między Stolicą Apostolską a państwem pruskim. Po dłuższym przygotowaniu, dnia 14 czerwca 1929 roku zawarty został konkordat. W imieniu papieża tekst podpisał nuncjusz apostolski arcybiskup Eugeniusz Pacelli, a w imieniu rządu pruskiego ministrowie: Otto Braun, Karol Becker i Hermann Höpker-Aschoff. ${ }^{35}$

Po myśli zawartego konkordatu wyłączono spod jurysdykcji biskupa wrocławskiego okręg delegatury berlińskiej tworząc na tym terenie diecezję berlińską. Nowa diecezja objęła około 60.000 kilometrów kwadratowych i około 540.000 katolików, 78 erygowanych parafii i 76 placówek duszpasterskich, oraz 248 duchownych. ${ }^{36}$ Granica między nowo erygowanym biskupstwem berlińskim a arcybiskupstwem wrocławskim na wschodzie brała początek od rzeki Drawy około 3 kilometrów na północ od miejscowości Dobiegniew. Włączała do Wrocławia Strzelce Krajeńskie, Bralinek i Myślibórz. Między Chojną a Moroniem nieco na północ od Cedyni stykała się z Odrą, około 5 kilometrów biegła jej karytem na poludnie, odeszla nieco od zachodniego brzegu i nie zmieniając kierunku na południe $w$ połowie odległości między Kostrzyniem a Frankfurtem i następnie między Frankfurtem a Rzepinem lukiem powracała na zachodni brzeg Odry pozostawiając przy Berlinie Frankfurt, a przy Wrocławiu w następnym łuku Beeskow, Lübben, Finsterwalde i doszła do punktu lączącego trzy diecezje: wrocławską, berlińską i paderborneńska. ${ }^{37}$ Wrocław przez długi czas zależny bezpośrednio od Stolicy Apostolskiej z dniem 13 sierpnia 1930 roku stał się centrum nowej prowincji kościelnej. Jako sufraganie wlączono do metropolii wrocławskiej: biskupstwo warmińskie, w ostatnich czasach bezpośrednio zależne od Stolicy Apostolskiej, nowo utworzone biskupstwo berlińskie i prałaturę pilską zorganizowaną po pierwszej wojnie światowej z zachodnich częsci archidiecezji gnieźnieńsko-poznańskiej i chełmińskiej polożonych na terenie Prus. ${ }^{38}$

${ }^{34}$ Real-Handbuch..., dz. c., cz. 1, s. 133.

${ }^{35}$ Eng e lbert K., Geschichte..., dz. c., s. 201 ns.

${ }^{30}$ Engel bert K., Adolf Kardinal Bertram..., dz. c., s. 16.

s7 Atlas..., dz. c., nr 321a; - Handbuch des Bistums Breslau und seines Delegatur-Bezirks für das Jahr 1918, Breslau, s. 105 ns.

${ }_{38}$ Bulla apostolska Pastoralis Officii Nostri, W: Kirchliches Amtsblatt 
Patrioci polscy zachęceni organizacyjnymi zmianami Kościola w Prusach, wypowiedzieli się dnia 7 maja 1931 roku na lamach polskiej prasy ${ }^{39}$ żądając utworzenia na Opolszczyźnie biskupstwa $\mathrm{z}$ polskim biskupem i otwarcia polskiego seminarium duchownego kierowanego przez Polaka. Na biskupa proponowano księdza doktora Pawła Łukaszczyka $\mathrm{z}$ Wroclawia, a na rektora seminarium księdza doktora Antoniego Korczoka z Gliwic. Poinformowano, że udokumentowane pisma w tej sprawie zostaly przesłane do Rzymu. Mimo licznych starań w czasie międzywojennym do stworzenia nowej diecezji w Opolu nie doszło. ${ }^{40}$

Archidiecezja wroclawska w roku 1930, a więc po ostatecznym ukształtowaniu granic obejmowała 2,2 mil. Katolików, 788 parafii, 56 kuracji, 23 lokalii zlączonych w 84 dekanatach. 11 Pod względem liczby wiernych archidiecezja kolońska obejmowała w Rzeszy Niemieckiej pierwsze miejsce, a drugie miejsce zajmowała archidiecezja wrockawska. ${ }^{42}$ Obok katolików mieszkało na terenie archidiecezji wrocławskiej 3.192 .123 protestantów, 47.178 wyznania mojżeszowego, 24.413 wyznania czeskiego, 37.984 innowierców, 62.262 bezwyznaniowych, a więc razem tuż przed 1930 rokiem ponad 5,5 mil. ludności. ${ }^{43}$ Od wschodu archidiecezja wrocławska graniczyła $z$ prałaturą pilską, archidiecezją gnieźnieńsko-poznańską, diecezją częstochowską i katowicką. Od południa sąsiadowała $z$ archidiecezją olomuniecką $\mathrm{i}$ praską, oraz $\mathrm{z}$ biskupstwem Hradec-Kralowe i Lutomierzyce. Od zachodu i północy dotykała terytorium diecezji miśnieńskiej, paderborneńskiej i berlińskiej. ${ }^{44}$

Po przyłączeniu Zaolzia do Polski, na zasadzie IX artykulu konkordatu, ${ }^{45}$ Stolica Apostolska dnia 4 listopada 1938 roku ${ }^{46}$ wyjęla spod jurysdykcji kardynała Bertrama całe dekanaty: Frysztat, Jabłonków i Karwina, oraz parafie: Dobracice, Domasławice, Gnojnik z dekanatu Frydek i Pietwald $z$ dekanatu Sląska Ostrawa i podporządkowała biskupowi katowickiemu jako administratorowi apostolskiemu. ${ }^{47}$ Pozostałe parafie dekanatu Frydek i Śląska Ostrawa polożone w Republice Czechosłowackiej były poddane biskupiej administracji arcybiskupa z Olo-

des Erzbischöflichen Ordinariats in Breslau (skrót: Kirchl. Amtsbl.), 11 (1930), s. 94.

${ }_{39}$ Katolik, Katolik codzienny, Nowiny codzienne, Dziennik Raciborski, Dziennik Berliński.

$40 \mathrm{~K} \mathrm{u} \mathrm{m}$ or B., dz. c., s. 389.

41 Eng e 1 be r t K., Adolf Kardinal Bertram..., dz. c., s. 17.

42 Moh re n J., Kirchliche Statistik Deuschlands, W: Kirchliches Handbuch (skrót: Kirchl. Handb.), t. 21 (1939) s. 354.

43 Real-Hardbuch..., dz. c., cz. 2, s. 488.

${ }^{44} \mathrm{R}$ og a ls k i A., dz. c., mapa biskupstwa wrocławskiego nlb.

45 乇 u k o s k i S., Konkordat zawarty dnia 10 lutego 1925 roku pomiędzy Stolica Apostolskq i Rzeczpospolita Polska, Łomża 1934, s. 97.

${ }_{46} \mathrm{~S} \mathrm{migiel} \mathrm{K}$., Whadze kościelne na polskich ziemiach inkorporowanych do Rzeszy niemieckiej 1939-1945, Pr. kan., 3-4 (1971), s. 164.

47 Handbuch des Erzbistums Breslau für das Jahr 1939, Breslau, s. 126 ns. 
muńca i pod jego zarządem pozostaly do smierci kardynała Bertrama.48 Gdy Polska we wrześniu 1939 roku stracila wolność, kardynal Bertram porozumiał się z biskupem katowickim i jego wikariuszem generalnym dla Zaolzia i wniósł dnia 9 grudnia 1939 roku pismo do Nuncjusza Apostolskiego $w$ Berlinie o ponowne włączenie pod jego jurysdykcję terytcrium Zaolzia okupowanego przez Niemców, a pozostającego pod kościelną władzą biskupa katowickiego. Prośba wspominała, że w listopadzie dwa razy jeździł na terytorium „Olsagebiet” kanonik Józef Ferche i stwierdzil ogólne oczekiwanie powrotu do macierzystej diecezji. Inne wysunięte argumenty to:

1. konieczność zaopiekowania się klasztorem jezuitów w Zachodnim Cieszynie, w którym znajduje się równiė mieszkanie proboszcza parafii Serca Jezusowego,

2. zaradzenie duszpasterskim brakom personalnym,

3. udzielenje duchownym pomocy, co przekrarcza możliwości biskupa Katowic. ${ }^{49}$

Stolica Apostolska przychylila się do prosby i od 1 stycznia 1940 roku kardynał Bertram $\mathrm{z}$ powrotem objął zarząd nad tą częścią diecezji. 50 Do 1945 roku żadnych przesunięć granicznych już nie było.

\section{Podzial terytorium na części}

Na skutek wojny, które w pierwszej połowie XVIII wieku prowadzily między sobą Prusy i Austria, prawie cała diecezja wrocławska dostała się od 1742 roku pod panowanie pruskie. W Austrii pozostała część dawnego księstwa nyskiego z kilkoma mniejszymi posiadlościami wielkopańskimi na Morawach, oraz wschodni Sląsk zwany Sląskiem Cieszyńskim. ${ }^{51}$ Władze kościelne podejmowały starania, by terytorium diecezji dostosować do granic państwowych na drodze wymiany części austriackiej diecezji wrocławskiej za pruską część diecezji ołomunieckiej. Nie znalazło to jednak właściwego poparcia, ani zrozumienia ${ }^{52}$ i nie zostało calkowicie załatwione. Polityczny podział diecezji wrocławskiej przyczynił się do jej wewnętrznego podziału na dwie części: pruską i austriacką, które stanowily jedną diecezję. $\mathrm{Z}$ wyjątkiem przejściowego okresu w drugiej pcłowie XVIII wieku pozostawały pod władzą jednego biskupa, ale posiadały odrębne wikariaty generalne. Prawo przedkodeksowe domagało się prawnego zwyczaju lub papieskiego indultu dla mianowania kilku wikariuszów generalnych $z$ racji politycznego po106.

48 Handbuch des Erzbistums Breslau für das Jahr 1942, Breslau, s.

49 Kard. Bertram do abpa Orseniego dn. 9.12.1939 r. (annexe), W: Le Saint Siege et la situation religieuse en Pologne et dans les pays Baltes, wyd. Blet Pierre $i$ in., Cittá' del Vaticano 1967, partie 1, s. 150. $50 \mathrm{~S}$ m i g i e l K., dz. c., s. 164 .

51 Allgemeine Uebersicht des Bisthums Breslau in seinen Geist- und Weltlichen Behörden, Breslau 1802, s. 111.

52 R०g a ls ki A., dz. c., s. 41; 
działu terytorium diecezji. ${ }^{53}$ Również po kodeksie autorzy utrzymują, że stuletni zwyczaj jest podstawą mianowania wikariusza generalnego na teren polity.cznie określony. ${ }^{54}$

Część pruska diecezji wrocławskiej stanawiła własciwe biskupstwo. Terytorialnie obejmowała wszystkie ziemie zakreślone zewnętranymi granicami diecezji pozostające pod panowaniem Prus. Wschodnie jej granice uległy zmianie w 1925 roku na skutek erekcji diecezji katowickiej. Wewnętrznie była dobrze zorganizowana. Posiadała wszystkie instytucje potrzebne do właśoiwego funkcjonowania diecezji. Należały do nich: urząd generalnego wikariusza, sąd kościelny pierwszej, drugiej i trzeciej linstancji, komisja do zarządu majątkiem wygasłych parafii, kancelaria urzędu generalnego wikariatu, główna kasa biskupstwa, prosynadalni 'sędziowie i konsultarzy, zarząd funduszu kapłańskiego, książęco-biskupi alumnat id konwikt teologiczny, konwikty dla chłopców w Bytomiu, Gliwicach, Głogowie, Nysie i Wrocławiu, dom dla księży emerytów, dom poprawczy dla duchownych i diecezjalne towarzystwo ubezpieczenia od agnia. ${ }^{55}$ Niektóre $z$ tych instytucji służyły również austriackiej części biskupstwa i delegaturze berlińskiej.

Cz ęść a u stria c ka diecezji wrocławskiej wyodrębniła się w czasie rządów biskupa Filipa Gattharda Schaffgotscha (1747-1795), który początkowo był popierany przez Fryderyka II, a potem popadł w nielaskę. Król odebral mu władzę duchowną nad pruską częścią diecezji. Prześladowany biskup zmuszony był opuścić Prusy i udać się do Austrii. Zamieszkal na stałe $w$ zamku Janowa Góra stanowiącym własność biskupów wrocławskich, skąd rządził częścią diecezji politycznie zależną ad Austrii. ${ }^{58}$ Austriacka czesść diecezji nie stanowiła zwartego terytorium. Przedzielona była pasmem należącym do diecezji ołomunickiej biegnącym z północnego wschodu na południowy zachód. Dla zapewnienia lepszej opleki duchowej, w tej części diecezji biskup Schaffgotsch ustanowil w roku 1771 ossobnego oficjała.57 Po śmierci biskupa Schaffgotscha cesarz uzależnił zatwierdzenie jego następcy quoad temporalia ad przyjęcia pod przysięgą zobowiązania, że dla austriackiej czẹści diecezji zaproponuje, a po zatwierdzeniu przez cesarza zamianuje tamtejszego duchownego wikariuszem generalnym. Postara się dla niego - godność biskupią i udzieli mu wszelkich pełnomocnictw dodając odpowiedni personel. Na utrzymanie generalnego wikariusza $\mathfrak{i}$ współpracownikow wyznaczona została odpowiednia kwota $\mathrm{z}$ dochodow bisku-

${ }^{33} \mathrm{~L}$ ae $\mathrm{mm}$ e r H., Institutionen des katholischen Kirchenrechts, Freiburg in Breisgau 1892, s. 266 ns.

54 Coronata M., Institutiones Iuris Canonici, t. 1, Taurini 1950, $\operatorname{nr} 419,2^{\circ}$; - Sztafrowski E., Wspótpracownicy biskupa diecezjalnego $w$ pasterskim postugiwaniu, Warszawa 1968, s. 22.

55 Handbuch... 1918, dz. c., s. 12 ns.

56 L on dz in J., dz. c., s. 4 ns.

57 Eng elbert K., Geschichte..., dz. c., s. 348; - Negwer J., Die Verwaltungseinrichtungen der Breslauer Erzdiözese in Geschichte und Gegenwart, Breslau 1935, s. 11; - Real-Handbuch..., cz. 2, s. 397. 
pich. ${ }^{58} \mathrm{Z}$ pośród dziesięciu następujących po sobie wikariuszów generalnych godność biskupią uzyskał ks. Franciszek Sniegon. Konsekracja biskupia odbyła się $w$ Cieszynie dnia 30 września 1883 roku. Brali w niej czynny udział: książe-biskup wrocławski Robert III Herzog, biskup krakowski Albin Dunajewski i biskup sufragan wrocławski Hermann Gleich. ${ }^{59}$ Obok wikariusza generalnego wielką rolę w kierowaniu tą cześcią diecezji odgrywali radcy. Sprawy procesowe małżeńskie, a później równileż kanne prowadził miejscowy sądu duchowny, który obok prezesa $w$ asobie wikariusza generalnego posiadał 3-4 rad$c \delta$ w, obrońce węzła małżeńskiego i notariusza. Powołane były dwa zespoly egzaminatorów prosynodalnych. Jeden dla komisariatu cieszyńskiego, a drugi dla kamisariatu nyskiego. ${ }^{80}$ Od 1905 roku powolywano jeden zespół egzaminatorów. ${ }^{\circ 1}$ Sprawy kancelaryjne w cieszyńskim generalnym wiikariacie początkowo wykonywali wikkariusze parafii, w której urząd mial swoją siedzibę. W końcu XIX wieku wikariusze w szerszym zakresie zajęci byli pracą duszpasterską. Nie mogli podołać zadaniom wikariusza, oraz sekretarza, protokólanta, registratora i ekspedienta pocztowego. Książe-biskup Jerzy Kapp stworzył w roku 1891 urząd kanclerza. ${ }^{62}$ Obok mianowanych na wyżej wymienione urzędy, powoływano różnego rodzaju radców honorowych. W 1897 noku w tej częsci diecezji było trzech książęco-biskupich radców duchownych pracujących na stałe w diecezji odomunieckiej, jedenastu tytularnych radców urzędu generalnego wikariatu i jeden radca książęco-biskupiej kancelarii. ${ }^{63}$ Urząd generalnego wikariatu przez sto lat wędrował po całym Kisięstwie Cieszyńskim i obok Cieszyna mieścił sie w Frydku, Morawce, Frysztacie, Bielsku i Strumieniu. Od 1872 roku stałą siedzibą był Cieszyn. ${ }^{64}$ Kardynał Jerzy Kopp rozbudował organizacyjnie cieszyński generalny wikariat. Powstały tu prawie wszystkie instytucje na wzór wroclawskiego generalnego wikariatu, a nawet własne seminarium duchowne. Kandydaci do święceń kapłańskich z tezo terenu odbywali studia teologiczne ra uniwersytecie i w seminarium duchownym w Olomuńcu. Dnia 17 paździemika 1899 roku rozpoczęło swą działalność wychowawczo-naukową seminarium duchowne w Widnawie. ${ }^{65}$

${ }^{58} \mathrm{~L}$ on d $\mathrm{z}$ in J., dz. c., s. 6.

59 Tamże, s. 29; - Real-Handbuch..., dz. c., cz. 1, s. 130.

60 Schematismus des Bisthums Breslau und seines Delegatur-Bezirks für das Jahr 1891, Breslau, s. 221 ns.

61 Schematismus des Bisthums Breslau und seines Delegatur-Bezirks für das Jahr 1906, Breslau, s. 104.

${ }_{62} \mathrm{~L}$ o n d $\mathrm{z}$ in J., dz. c., s. 77;

B3 Schematismus des Bisthums Breslau und seines Delegatur-Bezirks für das Jahr 1897, Breslau, s. 238 ns.

${ }^{64} \mathrm{~L}$ o n d z in J., dz. c., s. 39 ns.;

${ }^{65} \mathrm{H}$ a rbich K., Die Philosophisch-theologische Diözesanlehranstalt und das Priesterseminar in Weidenau, W: Engelbert K., Geschichte des Breslauer Domkapitels in Rahmen der Diözesangeschichte vom. Beginn des 19 Jahrhunderts, bis zuin Ende des Zweiten Weltkrieges, Hildesheim 1964, s. 404 ns.; - Real-Handbuch..., dz. c., cz. 2, s. 398. 
Granice zewnętrzne cieszyńskiego wikariatu generalnego nie uległy zmianom. W sprawie wewnętrznego podziału terytorialnego wikariusz generalny i radcy nie mieli decydującego głosu. Tworzenie, lączenie, znoszenie i wszelkie zmiany granic parafii należały do wyłącznej kompetencji księcia-biskupa. ${ }^{66}$ Po rozpadzie monarchii austro-węgierskiej w dniu 28 października 1918 roku ogłoszona została proklamacja o niepođległości Czechosłowacji. Granice ustalono traktatami: wersalskim i w Saint Germain w 1919 roku i w Trianon w 1920 roku. Spór graniczny między Polską a Czechosłowacją rozstrzygnięto przez arbitraż międzynaradowy w lipou 1920 roku. Przedstawiciele W. Brytanii, Francji i Włoch przyznali Czechosłowacji znaczną część Spiszu i Orawy, oraz zachodnią częsć Sląiska Cieszyńskiego. Polska otrzymała małą część Spiszu i Orawy, oraz wschodnią część Sląska Cieszyńskiego. W ten sposób komisariat cieszyński został podzielony na dwie części. Północno-wschodnia część znalazła się w politycznych granicach Piolski, a poludniowo-zachodnia $w$ Czechosłowacji. $Z$ chwila utworzenia administracji apostolskiej dla polsikiej części Górnego Sląska, polska część cieszyńskiego generalnego wikariatu pozostała nadal pod władzą biskupa wrocławskiego. Miejscowym rządcą-wikariuszem generalnym był wówczas ks. Jerzy Kolek, który piastował ten urząd od 16 maja 1902 roku. ${ }^{67}$ Bullą Vixdum Poloniae unitas w roku 1925 terytorium to zostało włączone do nowoerygowanej diecezji katowickiej. Ks. Jerzy Kolek liczył wtedy 85 lat życia. Z upoważnienia nominata ks. dr Augusta Hlonda urzędował jeszcze do konca listopada 1925 roku. Następnie przeszedł $w$ stan spoczynku. Kanclerz $\mathrm{ks}$. Wilhelm Kasperlik otrzymał stanowisko $\mathrm{W}$ katowickiej kurii biskupiej. ${ }^{68} \mathrm{~W}$ ten sposób przestal istnieć generalny wikariat w Cieszynie. Terytorium położone na terenie Czechosłowacji podległe biskupowi wrocławskiemu ujęte w dwa biskupie komisariaty dla czeskiego Sląska wschodniego i czeskiego Sląska zachodniego powoli zatracało swój odrębny charakter. Kardynał Bertram udzielif tamtejszym komisarzom. uprawnień generalnego wikariusza. Prowadził z nimi regularnie konferencje, a ważniejsze sprawy załatwiał osobiście. Nie było to trudne, gdy weźmie się pod uwagę, że kardynał latem przez dłuższy czas rezydował na zamku Janowa Gora. ${ }^{\circ 9}$ Powstale przed 1925 rokiem instytucje: oficjal, wiceoficjał, promator sprawiedliwości, obrońca węzła małżeńskiego, notariusze, sędziowie, konsultorzy, oraz egzaminatorzy synodalni i prosynodalni funkcjonowały do 1938 roku. ${ }^{70}$ Seminarium Duchowne $w$ Widnawie przetrwalo do 1945 roku. Po przyłączeniu przez Niemcy hitlerowskie tzw. Kraju Sudeckiego, komisariat czeskiego Sląska zachodniego ściśle zlączono z Wrocławiem

66 L o n d z in J., dz. c., s. 39 ns.

67 Schematismus..., 1914, s. 120.

${ }_{68} \mathrm{~L}$ on d $\mathrm{z}$ in J., dz. c., s. 75 ns.

${ }^{89} \mathrm{~N}$ e g w e r J., dz. c., s. 38.

70 Handbuch des Erzbistums Breslau für das Jahr 1938, Breslau, s. 121 ns., s. 131 ns. 
i nie było patrzeby utrzymywać odrębne urzędy. Terytorium to zostało poddane wroclawskiemu wikariuszowi generalnemu. Wewnętrznego podziału nie zmieniono, a komisarz biskupi zachował uprawnienia zgadnie z piastowanym urzędem. ${ }^{71}$ Komisariat wschodniego Sląska czeskiega przechơdził znaczniejsze zmiany, o których już wyżej była mowa.

Okręg Delegatury' Berlínskiej przylegał do północnych granic pruskiej części biskupstwa wroclawskiego. Obejmował on Pomorze i Brandenburgię $\mathrm{z}$ wyjątkiem małej części, która wrchodziła w skład właściwego biskupstwa wrocławskiego. Obszar ten prawie całkowicie został zalany przez protestantyzm. Kościół dla ratowania resztek katolicyzmu ustanowił Apostolski Wikariat Misji Północnych. Na początku XIX wieku należało do niego sześć bardzo rozległych parafii, których wierni żyli w "diasporze". ${ }^{72}$ Bullą De salute animarum terytorium wikariatu zostalo, ,na zawsze oddane pod zarząd przyszlego biskupa wroclawskiego". Z woli Stolicy Apostolskiej w imieniu biskupa wroclawskiego mial sprawować miejscowe rządy ,vi subdelegationis" proboszcz: parafii św. Jadwigi $w$ Berlinie. ${ }^{73}$ Stąd trzeba wnosić, że na terenie delegatury każdy biskup wrocławski posiadał władzę delegowaną. Wszystkie sprawy delegatury przechodzące zakres uprawnień udzielonych proboszczowi parafii św. Jadwigi w Berlinie, załatwiane były w osobistej książęco-biskupiej kancelarii. Wrocławski generalny wikariat nie posiadał $\mathrm{w}$ odniesieniu do tego terytorium żadnych uprawnien. ${ }^{74}$ Dokument wydany przez papieża $w$ porozumieniu $z$ rządem staro-pruskim miał na uwadze interesy kościelne i państwowe. Dla Stolicy Apostolskiej uciążliwe było klierowanie ì utrzymywanie Wikariatu Misji Półnoenych. Oddanie tego terytorium w zarząd biskupowi sąsiedniei diecezji materialnie zasobnej i posiadającej dobrze przygotowane duchowieństwo, ułatwiało prace i gwarantowało większy rozwój. Wprowadzało to również bardziej stałą organizację niż wilsariat apostolski, na czym zależało Kościołowi i Prusom. Berlin jako stolica państwa nabierał znaczenia i najprawdopodobniej już wtedy został przewidziany na siedzibę biskupstwa. Nie wypadało, aby włączać go w sposób pospolity do diecezji wrocławskiej. Przez stworzenie delegatury zyskiwal pomoc ze strony Wroclawia, a równocześnie był w pewien sposób jednostką wyodrębnioną. Wszystkie schematyzmy podają na karcie tytułowej: „Schematismus (Handibuch) des Bistums Breslau und seines Delegatur Bezirks für das Jahr...". Wewnątrz umieszczają delegaturę po pruskiej

${ }^{71}$ Eng e I be r t K., Geschichte..., dz. c., s. 238.

${ }^{72}$ Seppelt F., Geschichte des Bistums Breslau, Breslau 1929, s. 93.

${ }^{73}$ Bulla De salute animarum, alinea 32, W: Engelbert K., Geschichte..., dz. c., s. 369, Określenie ,na podstawie pełnomocnictwa użyte przez Beiersdorfa O. W: Papiestwo wobec sprawy polskiej $w$ latach 1772-1864 - Wybór źródeł, zaciera różnice jaka istnieje między władzą delegowaną a subdelegowaną.

${ }^{71}$ Eng e I ber t K., Geschichte..., dz. c., s. 348 . 
części diecezji wrocławskiej, a przed austriacką. ${ }^{75}$ Zdanie Sauera „Der Delegatur-Bezirk steht daher mit der Diöcese Breslau in keiner andern Verbindung, als dass beide inter demselben Bischofe stehen", ${ }^{76}$ jest w pewnym zakresie pozbawione słuszności. Bulla wydana była podezas jednego z najdłuższych wakansów na wrocławskiej stolicy biskupiej, który trwał od 1817 do 1824 roku. Diecezją rząził jako administrator Emanuel Schimonsky-Schimoni pomocniczy biskup wrocławski. ${ }^{77}$ Oddanie na zawsze (perpetuo) wikaniatu apostolskiego w zarząd przyszłemu biskupowi wrocławskliemu stworzyło głębokie podstawy łączności na dalsze lata jego istnienia (pro tempore existentis), czyli do czasu przekształcenia w pelnoprawną diecezję. Jedność asoby biskupa jest wyrazem wspólnoty całej owczarni z pasterzem. Oceniając od strony praktycznej łącznosć delegatury z Wrocławiem była większa niż części austriackiej. Delegatura nie posiadała wlasnego sądu kościelnego i wszystkie sprawy małżeńskie, sporne i ikarne przekazywała do Wrocławia. $\mathrm{Na}$ wydziale teologicznym uniwersytetu wrockawskiego i $w$ alumnacie przygotowywano kandydatów do święcen kapłańskich i zależnie od potrzeb wysyłano ich $w$ charakterze misjonarzy do delegatury berlińskiej. W 1884 roku ponad $80 \%$ pracujących tam kapłanów urodziło się $i$ wyksztalciło $w$ pruskiej częsci biskupstwa wrocławskiego. ${ }^{78}$ $\mathrm{Na}$ przełomie XIX wieku i XX przybyło do Berlina wielu kapłanów $z$ niemieckich diecezji zachodnich, ale ciągle przewazali wrocławscy, wśród których widzimy ks. Jana Kapicę, ${ }^{79} \mathrm{ks}$. Stanisława Maślińskiego, ${ }^{80}$ ks. Michała Lewka, ${ }^{81}$ ks. Pawła Eukaszczyka ${ }^{82}$ i ks. Ludurika Cuno. ${ }^{83}$ Dwaj ostatni byli pomocnikami i sekretarzami delegata biskupiego.

Rzetelna praca kapłanów i napływ do Berlina katolików z różnych stron państwa pruskiego przekształcaly teren misyjny $w$ pewnego ro-

75 Por. Schematismus... 1897; - Handbuch... 1918.

${ }^{76} \mathrm{~S}$ a u e r J., Pfarramtliche Geschäfts-Verwaltung, Breslau 1868, s. 41.

77 Se p pelt F., dz. c. s. 93.

78 Schematismus des Bisthums Breslau und seines Delegatur-Bezirks für das Jahr 1884, Breslau, s. 113 ns.

${ }^{79}$ Schematismus... 1897, dz. c., s. 220; (posel do parlamentu pruskiego, dziekan w Tychach, prezes Sekcji Teologicznej przy Polskim Komitecie Plebiscytowym, delegat biskupi z prawami wikariusza generalnego na polską ezęść Gơrnego Sląska, prepozyt kapituły katowickiej).

$80 \mathrm{H}$ of fmann H., Die Geschichte des Breslauer Alumnats, Breslau 1935 , s. 259; (wicerektor alumnatu wroclawskiego, rektor Sląskiego Seminarium Duchownego $w$ Krakowie, proboszcz parafii NMP. w Katowicach).

${ }^{81}$ L e:w ek M., Górnośląski plebliscyt z noku 1921 oraz udział w nim duchowieństwa katolickiego, Rzym 1960, s. 6; (sekretarz Sekcji Teologicznej przy Polskim Komitecie Plebiscytowym, proboszcz w Tarnowskich Górach).

${ }_{82}$ Handbuch des Bistums Breslau und seines Delegatur-Bezirks für das Jahr 1908, Breslau, s. 94.

s3 Handbuch... 1918, dz c., s. 105. 
dzaju zorganizowaną jednostkę administracji kościelnej. Delegat otrzymał uprawnienia wikariusza generalnego i stworzono radę delegatury, jako kolegium złożone $\mathrm{z}$ berlińskich proboszczów. ${ }^{84} \mathrm{~W} 1923$ roku delegat kardynała Bertrama ks. Jozef Deitmer otrzymał sakrę biskupią. Był drugim biskupem pomocniczym dla Wrockawia $\mathrm{z}$ stedzibą $\mathrm{w}$ Berlinie. ${ }^{85}$ Bulla „Pastoralis of ficii Nostri” z dnia 13 sierpnia 1930 roku okręg delegatury traktowała jako administrację apostolską i przeksztakciła w pelnoprawną diecezje. ${ }^{86}$ Arcybiskup wrocławski posiadał w stosunku do Berlina nadrzędne uprawnienia metropolity według przepisów K.P.K.

\section{Wewnętrzny podzial poszczególnych części diecezji}

Diecezja wrocławska już $w$ wiekach srednich podzielona była na cztery archidiakonaty: wrocławski, głogowski, opolski i legnicki. Do obowiązków archidiakonów należako: przekazywać komisarzom i dziekanom wszystkie polecenia i zarządzenia generalnego wikariatu, oraz przeprowadzać co trzy lata generalną wizytację na podległym sobie terenie. ${ }^{87} \mathrm{~W}$ XIX wieku znika powoli instytucja archidliakonów. Dłuższy czas widzimy jeszcze archidiakona wrocławskiego, któremu w 1842 roku podlegało 17 dekanatów nie włączonych do żadnego komisariatu. ${ }^{88} \mathrm{Ty}-$ tuł archidiakona został utrzymany przy pokolegiackim kościele Wniebowzięcia Najświętszej Marii Panny w Głogowie, jako reminiscencja starej $i$ bardzo zasłużonej instytucji w organizacji Koscioła. ${ }^{89}$ W 1942 roku archidiakonat nie był złączony z urzędem komisarza biskupiego, dziekana, a nawet proiboszcza. ${ }^{30}$

Obok archidiakonatów już $\mathrm{w}$ XV wieku powstały w diecezji wrocławskiej biskupie komisariaty, w skład których wchodziły dekanaty zwane archiprezbiteratami. Głównymi zadaniami biskupich komisarzy byla kontrola pracy dziekanów w dekanacie i w ich parafiach, wprowadzanie szczególnych zarządzeń ordynariatu, przesyłanie sprawozdań i opinii, oraz wprowadzanie dziekanów na urząd. ${ }^{91}$ Kamisariat nie był urzędem jednoosobowym. Obok komisarza pełnili w nim obowiązki dwaj duchowni asesorzy i jeden biegły w prawie swiecki syndyk-radca prawny, albo notariusz. Taki sklad osobowy potrzebny był przy prowadzeniu procesów. Sprawozdania z działalności komisariatu przekazywano w każdym miesiącu do konsystorza lub generalnego wikariatu. Liczba

\footnotetext{
$84 \mathrm{~N}$ e g w er J., dz. c., s. 21.

${ }^{85}$ Real-Handbuch..., cz. 1 , s. 130.

86 Bulla Pastoralis officii Nostri, W: Kirchl. Amtsbl., 11 (1930), s. 94.

87 Allgemeine Uebersicht..., dz. c., s. 47 ; - Ne g w er J., dz. c., s. 6.

${ }_{88}$ Schematismus oder Statistik des Bisthums Breslau königlich Preussischen Antheils, Breslau 1842, s. 8.

${ }_{89}$ Real-Handbuch.., cz. 2, s. 23, 119; - Laemmer H., dz. c., s. 273 ; - S a u e r J., dz. c., s. 38.

90 Handbuch... 1942, dz. c., s. 40.

91 Real-Handbuch..., cz. 2, s. 23; - L a e m m e r H., dz. c., s. 273.
} 
komisarzy wahała się od trzech $\mathrm{w}$ XVII wieku do dziesięciu w połowie XIX wieku. ${ }^{92} \mathrm{~W}$ okresie rządów kardynała Bertrama władza komisarzy rozciągała się na sprawy administracyjno-duszpasterskie. Oprócz uprawnień posiadanych dawniej, brali udzial w synodach diecezjalnych, w konferencjach dziekanow, posiadali w granicach komisariatu delegowana władze rozgrzeszania $z$ cenzur i udzielania dyspens. Mieli abowiązek w każdym roku wizytować dziekanów, a sami wizytowani byli przez członka generalnego wikariatu. ${ }^{93} \mathrm{Nie}$ posiadali żadnych uprawnień $\mathrm{w}$ sprawach procesowych.

Terytorium podległe biskupowi wrocławskiemu w 1914 roku podzielone było na 13 komisariatów, które zawierały w sobie kilka lub kilkanaście dekanatów. ${ }^{94}$

Część pruska:

1. Komisariat Głogów: 12 dekanatów - Cottbus, Głogów, G6ra Sląska, Kożuchów, Neuzelle, Slawa Sląska, Swiebodzin, Szprotawa, Wysoka Cerkiew, Zielona Góra, Żagań, Przewóz;

2. Komisariat Jawor: 4 dekanaty - Bolków, Jawor, Legnica, Strzegom;

3. Komisariat Jelenia Góra: 7 dekanatów - Bolesławiec, Jelenia Góra, Kamienna Góra, Lubań, Lubomierz, Nowogrodziec, Wleń;

4. Komisariat Nysa: 7 dekanatów - Głuchołazy, Grodków, Nysa, Otmuchów, Paczków, Prudnik, Skoroszyce;

5. Komisariat Opole: 7 dekanatów - Biała, Byczyna, Niemodlin, Olesno Sląskie, Opole, Prószków, Siołkowice;

6. Komisariat Pszczyna: 7 dekanatów - Bytom, Chorzów, Mysłowice, Mikołów, Pszczyna, Tarnowskie Góry, Zabrze;

7. Komisariat Racibórz: 10 dekanatów - Dębieńsko, Gliwice, Gościęcin, Koźle, Łany, Pogrzebień, Racibórz, Tworków, Wodzisław Sląski, Żory;

8. Komisariat Strzelce Opolskie: 7 dekanatów - Głogówek, Lubliniec, Pyskowice, Strzelce Opolskie, Strzeleczki, Toszek, Ujazd;

9. Komisariat Wrocław: 9 dekanatów - Borów, Brzeg, Kąty Wroclawskie, Sw. Maurycego, Sw. Mikołaja, Oleśnica Sląska, Wiązów, Wrocław;

10. Komisariat Ziębice: 6 dekanatów - Dzierżoniów, Kamieniec Ząbkowicki, Kielczyn, Wałbrzych, Ziębice, Ząbkowice Sląskie;

11. Komisariat Żmigród: 8 dekanatów - Cerekwica, Milicz, Namysłów, Przychowa, Rychtal, Syców, Wołów, Żmigród;

Część austriacka:

1. Komisariat cieszyński: 8 dekanatów - Bielsko, Cieszyn, Frydek, Frysztat, Jabłonków, Karwina, Skoczów, Strumień;

92 N e g w e r J., dz. c., s. 10.

93 Tamże, s. 33.

94 Handbuch... 1914, dz. c., s. 14 ns.; - Handbuch des Bistums Breslau und seines Delegatur-Bezirks für das Jahr 1915, s. 14 ns. 
2. Komisariat nyski: 4 dekanaty - Freiwaldau, Johannesberg, Weidenau, Zuckmante!;

Komistariat cieszyński nazwano później komisariatem wschodniego Sląska czeskiego, ${ }^{95}$ a od 1940 Ioku komisariatem okręgu Olzy. ${ }^{96}$ Komisariat nyski stanowił dawniej część księstwa nyskiego i stąd wywodzi sie jego nazwa. Dla odróżnienia od komisariatu Nysa z pruskiej części biskupstwa, nazywany był komisariatem czeskiego Sląska zachodniego, ${ }^{97}$ a po zajęciu tego terytorium przez Niemcy hitlerowskie nosił miano komisariatu Freiwaldau. ${ }^{98}$

Okręg książęco-biskupiej delegatury dla marchiii brandenburskiej i pomorskiej nie byl początkowo podzielony na kcmisariaty biskupie. Mimo rozległości, posiadał bardzo małą liczbę dekanatów. W 1924 roku przeprowadzono nowy podzial terytorialny delegatury. Ze względu na odrębność Pomorza, stworzono wtedy $z$ dekanatów: Koszalin, Stralsund i Szezecin odrębny komisariat pomoraki. ${ }^{99}$

Przez przesunięcie wschodnich granic diecezji pomniejszyło się nieco terytorium komisariatu głogowskiego i żmigrodzkiego. $\mathrm{Z}$ komisariatu glogowskiego przydzielono północno wschodnią część dekanatu Góra Sląska do archidiecezji gniéźnieńsko-poznańskiej. Komisariat żmigrodzki stracił część dekanatu rychtalskiego i sycowskiego. Poza granicami komisariatu pozostrała również siedziba dekanatu Rychtal. Od tego czasu komisariat żmigrodzki obejmowal siedem dekanatów. Komisariat pszczyński przestał istnieć. Najwięcej zmian dokonano $w$ komisariacie raciborskim i cieszyńskim. Z komisariatu raciborskiego cztery dekanaty wes.zły w skład diecezji katowickiej, a w ich miejsce włączono dwa dekanaty z komisaniatu pszczyńskiego. W latach 1931-1937 powstały dwa nowe dekanaty: Łabędy i Miechowice $z$ podziału dekanatu gliwickiego li bytomskiego. Pozostawiono je w macierzystym komisariacie raciborskim. Dzięki uzupełnianiu i erekcji nowych dekanatów, liczba dekanatów w omawianym komisariacie od 1914 roku do 1945 nie uległa zmianie. Komisariat cieszyński po pierwszej wojnie światowej został znacznie pomniejszony. Dekanaty: Bielsko, Cieszyn, Skoczów i Strumień zostały wlączone do Katowic, a pozostały w nim dekanaty: Frydek, Frysztat, Jabłonków i Karwina. W 1927 roku powstał na tym terenie dekanat Sląska Ostrawa. ${ }^{100} \mathrm{Na}$ skutek przemian politycznych dwa dekanaty: Frydek i Sląska Ostrawa zostały oddane w administrację biskupią arcybiskupowi Ołomuńca. I tak komisariat Okręgu Olzy

${ }_{95}$ Handbuch des Erzbistums Breslau für das Jahr 1935, Breslau s. 114.

96 Handbuch... 1942, dz. c. s. 11.

97 Handbuch... 1935, dz. c., s. 122.

98 Handbuch... 1940, dz. c., s. 10; - Handbuch... 1942, dz. c., s. 11.

${ }^{99}$ Neuteilung der Archlipresbyterate des Delegaturbezirks, dekret $z$ dn. 8. 4. 1924, W: Verordnungen..., 7 (1924), s. 47 ns. 100 Real-Handbuch..., dz. c., cz. 2, s. 417. 
w ostatnich latach rządów kardynała Bertrama posiadał tylko trzy dekanaty: Frysztat, Jablonków i Karwina. ${ }^{101}$

Z komisariatu glogowskiego wydzielono dnia 18 lipca 1925 roku cztery okręgi duszpasterskie: Klettwitz, Senftenberg, Welzow, oraz Grossräschen i włączono do komisariatu jeleniogórskiego. ${ }^{102}$ Diecezja wracławska po erekcji biskupstwa berlińskiego posiadała 12 komisariatów, z których 10 leżało w granicach Rzeszy Niemieckiej, a 2 na terenie Czechosłowacji.

Z racji rozległości terytorialnej i dużej liczby wiernych, dnia 1 lipca 1943 roku wydzielono $\mathrm{z}$ komisariatu glogowskiego pięć dekanatów stwarzając z nich komisariat Neuzelle. Do nowego komisariatu weszły:

1. Cottbus

4. Swiebodzin

2. Gorzów Wielkopolski

5. Żary

3. Neuzelle

W komisariacie głogownskim pozostało osiem dekanatów:
1. Glogów
5. Szprotawa
2. Góra Sląska
6. Wysoki Kośció1
3. Kożuchów
7. Zielona Góra
4. Sława Sląska
8. Zary. ${ }^{103}$

Całe terytorium diecezji wrocławskiej w 1945 roku podzielone było na trzynaście komisariatów biskupich.

W pierwszej połowie XIII wieku diecezja wrocławska zastała podzielona na dekanaty. Najwcześniej, bo już w 1219 roku wspominany byl dekanat glogowsiki, mastępnie opolski w 1223 roku i żagański w 1272 roku. ${ }^{104}$ Już w XIV wieku liczba wzrosła do trzydziestu kilku. ${ }^{105} \mathrm{Na}$ początku XX wieku kardynal Kopp w pruskiej części biskupstwa erygowal dekanat: Cottbus, Chorzów, Koźle, Tworków i Zabrze, a w delegaturze berlińskiej: Charlottenburg, Neuköln i Stralsund. Dekanaty diecezji wrocławskiej obejmowały: parafie, 'iuracje i lokalie. Parafie obok świątyni parafialnej posiadaly często kościoiy zwane „mater adiuncta" i kościoły względnie kaplice filialne. Kosciól „mater adiuncta" był dawniej świątynią parafialną, ale z czasem wskutek zmniejszenia się liczby katolików lub dla powiększenia środków uitrzymania proboszcza sąsiedniej parafii, zostal do niej przyłączony ${ }_{2}$ wszystkimi dochodami i całym majątkiem. ${ }^{106}$ Przyłączenie to nie było równoznaczne ze zniesieniem parafii. Nie posiadala ona własnego, osobnego proboszcza, co czy-

101 Handbuch... 1942, dz. c., s. 11.

102 Real-Handbuch..., dz. c., cz. 2, s. 330; - Verordnungen..., 13 (1925), s. 69.

${ }^{109}$ Teilung des Kommissariats Glogau in die beiden Kommissariate Glogau und Neuzelle, W: Kirchl. Amtsbl., 12 (1943), s. 61.

${ }^{204}$ Real-Handbuch..., dz. c., cz. 2, s. 118, 268, 305.

105 Siln ick i T., dz. c., s. 352.

106 Schematismus oder Statistik..., dz. c., s. XVII. 
niło ją podobną do parafii nie cbsadzonej, ale zachowywała swoje terytorium i własne dotacje parafialne, a nawet osobny zarząd kościelny działający pod przewodnictwem proboszcza tej parafii, do której została przylączona. ${ }^{107}$ Nasilenie lączenia i znoszenia parafii w diecezji wrocławskiej zaznacza się $w$ drugiej połowie XVIII wieku po opanowaniu Sląska przez Prusy. Akcja ta szczególnie dotknęła północno-zachodnie tereny diecezji. Likwidacja katolickich parafii stwarzała lepsze warunki do zakorzeniania się protestantyzmu, który pomagał władzom pruskim w germanizacji Sląska. ${ }^{108}$

Kuracja i lakalia to placówki duszpasterskie, które nie były nigdy kościolami parafialnymi jak kościoły „mater adiuncta”, ani też kościolami fundacyjnymi czy klasztornymi. Nie stanowily prawdziwych beneficjów, bo brakowało im istotnych warunków. Były świątyniami dla wiernych zamieszkalych na okreslonym terenie. ${ }^{109}$ Nie posiadały ustalonych dochodów z pól, ląk, lasów (Wiedmuth), a dawniej z dziesięciny (Decemrecht), ${ }^{110}$ Kościelną wspólnotę kuracji lub lokalii ustanawiał biskup przy kościele lub kaplicy publicznej w miejscowości odległej od kościoła parafialnego, aby wiernym zapewnić lepszą obsługę duszpasterską. Dokument biskupa musiał otrzymać ratyfikację władzy państwowej. Kuracja po upływie czasu, gdy otrzymała odpowiednie dotacje mogla być erygowana jako benificjum parafialne. ${ }^{111}$ Duszpasterze z tytulem ,kuratus", „lokalista" mianowani byli najczęsciej $w$ niezależny spośbb dekretem biskupa lub wikariusza generalnego, chociaż mogli być wybierani lub prezentowani. Do obowiązków kuratusa i lokalisty należało pełnienie wszystkich funkcji parafialnych $w$ sposób prawie niezależny od proboszcza, na którego terenie leżał ich kościół. Prawodawstwo diecezjalne $w$ poszczególnych wypadkach okreslało ich uprawnienia i obowiązki. Kardynal Bertram dekretem $z$ dnia 25 marca 1935 roku określił ostatecznie ${ }^{112}$ stan prawno-kościelny kuracji i ich duszpasterzy. ${ }^{113}$ Od tego czasu istniały dwa rodzaje kuracji: samodzielne i zależne. Samodzielne kuracje, jako okręgi duszpasterskie po myśli kan. 1427 K.P.K. tworzył biskup na zasadach publiczno prawnych $w$ porozumieniu $z$ władzami państwowymi przez wylączenie dekretem pewnego terytorium z macierzystej parafii. Duszpasterze tych kuracji z reguły

${ }^{107} \mathrm{~N}$ e g w e r J., dz. c., s. 35.

${ }_{108} \mathrm{U} \mathrm{r}$ ban W., Leopold hr. Sedinicki ksiqże biskup wroctawski 1836-1840, Warszawa 1955, s. 89.99.

$109 \mathrm{~K}$ o e n ige r A. M., Katholisches Kirchenrecht mit Berücksichtung des Deutschen Staatskirchenrechts, Freiburg in Breisgau 1926, s. 239.

110 L a e m m e r H., dz. c., s. 286.

111 S. C. Conc, rozstrzygnięcie $z$ dn. 13. 7. 1918 r., Missae pro populo, $\mathrm{W}$ : Verordnungen..., 15 (1918), s. 110.

${ }^{112}$ Tamże, podaje poprzedni stan prawno-kościelny kuracji i lokaliii. ${ }^{113}$ Kirchenrechtliche Verhältnisse der Kuratie-Gemeinden und ihrer Seelsorger, W: Kirchl. Amtsbl., 6 (1935), s. 43 ns. 
nominowani byli z pośród kapłanów, którzy złożyli egzaminy proboszczowskie. Zwalniani byli ad nutum episcopi. Posiadali oni uprawnienia i obowiązki proboszcza w/g kan. $451 \S 2 \mathrm{nr} 2$ i kan. 462 K.P.K.:

a. prowadzili księgi parafialne i używali pieczęai,

b. urzędowo podpisywali się: Kuratial-Pfarrer, albo Pfarrkuratus,

c. odprawiali msze św. pro populo, ${ }^{114}$

d. brali udzial $\mathrm{z}$ prawem aktywnym $\mathrm{w}$ wyborach notariusza okręgowego (wicedziekana),

e. mogli nosić odznaki proboszczowskie.

Zależne kuracje tworzył ordynariusz wydzielając część terytorium z macierzystej parafii i powierzając pieczę duszpasterską wikariuszowi współpracownilkowi, jako głównemu duszpasterzowi na tym określonym terenie, który pozcstawal w lączności $z$ parafią i pod nadzorem proboszcza. Proboszcz zatrzymywal swoje kompetencje, ale $z$ reguły nie korzystał $z$ nich bez porozumienia sie z kuratusem-lokalistą. Odnośnie kościoła, kuratus był rektorem z prawami i obowiązkami wypływającymi z kan. 479 K.P.K. przewodniczącym rady kościelnej, o ile kuracja posiadała samodzielny majątek. Przy nominacji otrzymywał często uprawnienia wykonywania funkcji zastrzeżonych proboszczowi wedrug kanonu 462 K.P.K.:

a. posiadał prawo asystowania przy zawieraniu małżeństw po myśli kan. $476 \S 6$ i w poszczególnych wypadkach mógł subdelegować,

b. mógł udzielać dyspens i absolucji,

c. prowadził asobne księgi parafialne i wydawał urzędowe wypisy i zaświadczenia,

d. posługiwał się urzędową pieczęcią i podpisywał się: Kuratus.

Nie był obowiązany do odprawiania mszy św. pro populo, ponieważ czynił to proboiszcz, $z$ którego parafiil lokalia była wydzielona. Bral udział $w$ zjazdach i konferencjach dekanalnych jak inni duszpasterze, ale nie uczestniczyl w wyborach notariusza okręgowego. Urlopy i zastępstwa otrzymywal kuratus na zasadach ustalonych dla duchownych pomocniczych.

W 1914 roku jurysdykcji biskupa Bertrama podlegało 105 dekanatów, z czego $84 \mathrm{w}$ pruskiej części biskupstwa, w 12 części austriackiej, a 9 w delegaturze berlińskiej.115 Kilka dekanatow nosiło nazwy swiętych lub małych miejsoowośdi, co stwarzało pewne trudności administracyjne. $\mathrm{Na}$ wniosek generalnego wikariatu kardynał Bertram zmienił w 1924 roku nazwę dekanatu Byczyna na Kluczbork, Cerekwica na Trzebnica, Kielczyn na Swidnica Sląska, świętego Maurycego na Olawa, świętego

114 Sprawę odprawiania mszy św, pro populo przez duszpasterza kuracji rozstrzygnęla po wydaniu K.P.K. Swięta Kongregacja Soboru. Por. S. C. Conc., 13. 7. 1918 r., Missae pro populo, W: Verordnungen..., 15 (1918), s. 110.

115 Por. Handbuch... 1914, dz. c. 
Milkolaja na Wroclaw-Leśnica, Przewóz na Zary i Przychowa na Scinawa. ${ }^{116}$

Po zakończeniu pierwszej wojny światowej znaczny wpływ na przynależność parafii do dekanatów miały państwowe przesunięcia graniczne. Rozdzielone zostały nie tylko terytoria dekanatów, ale nawet poszczególnych parafiil. Stąd wiele parafii trzeba bylo włączyć do sąsiednich deksanatów. W 1922 roku włączono:

1. parafię Bujaków z dekanatu zabrzańskniego do dębińskiego,

2. parafię Dobrodzień $\mathrm{z}$ dekanatu lublinieckiego do opolskiego,

3. parafię Markowice $\mathrm{z}$ dekanatu pogrzebieńskiego do raciborskiego,

4. parafię Pilchowice $\mathrm{z}$ dekanatu dębińskiego do gliwickiego,

5. parafię Sieraków i lokalię Zborowskie z dekanatu lublinieckiego do olesneńskiego.

Z placówek duszpasterskich dekanatu Bytom i Zabrze pozostalych po wschodniej stronie granicy polsko-niemieckiej erygowano w 1922 roku dekanat Ruda Sląska. W jego skład weszły: $z$ dekanatu Bytom Nowy Bytom, Godula, Lipiny, Orzegów i z dekanatu Zabrze - Bielszowice, Kończyce, Pawłow i Ruda Sląska. ${ }^{117}$ Dekanat ten wszedł w skład delegatury biskupiej dla polskiego Sląska Górnego, a później diecezji katowickiej. Parafie diecezji wrockawskiej przydzielone po 1918 roku do województwa poznańskiego pochodzące z dekanatu Rychtal i Syców zespolono w jeden dekanat rychtalski (,,alle in Neupolen”). Częśc dekanatu rychtalskiego leżącą po stronie niemieckiej włączono do dekanatu namysłowskiego. Nowrookreślone dekanaty obejmowały następujące parafie:

1. dekanat Rychtal: Bralin, Krzyżownik, Nowa Wieś Książęca, Marcinki-Mąkoszyce, Trębaczów, Turkowy;

2. dekanat Namysłów: Bąkowice, Biestrzykowice, Głuszyna, Kowalowice, Michalice, Namysłów, Pokój, Siemysłów-Starościn, Smogorzow, Strzelce-Gręboszow, Whochy, Woskowice Małe;

3. dekanat Syców: Dziadowa Kłoda, Drołtowice, Międzybórz, Ostrowina, Syców, Szczodrów. ${ }^{118}$

Tak uksztaltowany dekanat Rychtal na mocy bulli „Vixdum Poloniae” wszedł do archidiecezji gnieźrieńsko-poznańskiej. Parafia Dobrodzień z dekanatu Lubliniec włączona w 1922 roku do dekanatu Opole, stała sie 1 kwietnia 1926 roku siedzibą dekanatu, ${ }^{119}$ do którego włączono:

1. z dekanatu Opole: Dobrodzień, Krasiejow, Staniszcze Wielkie, Szemrowice;

2. z dekanatu Olesno Sląskie: Zębowice;

116 Anderung in Benenung der Archipresbyterate, dekret $\mathrm{z}$ dn. 24. 11. 1924, W: Verordnungen..., 19 (1924), s. 107.

117 Verordungen..., 7 (1922), s. 31.

118 Tamże, 14 (1923), s. 118.

119 Real-Handbuch..., dz. c., cz. 2, s. 144.

10 - Prawo Kanoniczne 
3. z dekanatu Pyskowice: Tworóg, Kot;

4. $z$ dekanatu Toszek: Kielcza, Zawadzkie, Zędcwice. ${ }^{120}$

Do największych przestrzennie należał dekanat Cattbus ${ }^{121}$ i Luban. ${ }^{122}$ Pierwszy obejmował powiat Cottbus, oraz parafie z powiatów: Calau, Luckau, Spremberg i Żary. W skład drugiego wchodził powiat Luḅan, oraz w calości lub w części powiaty: Bolesławiec (jedna parafia), Hoyerswerda i Zgorzelec. Ze względu na ich rozległość dnia 18 lipca 1925 roku ${ }^{123}$ wydzielono $z$ dekanatu Lubań parafie: Hoyerswerda z Lautawerk, Bernsdorf i Wittichenau, a z dekanatu Cottbus parafie: Klettwitz, Senftenberg oraz Grossräschen stiwarzając z nich nowy dekanat Senftenberg. ${ }^{124}$ Nowy dekanat włączony został do kamisariatu biskupiego Jelenia Góra. ${ }^{125}$

Katedra wrocławska pozostawała poza organizacją dekanainą, chociaż stanowwika parafię liczącą ckoło 500 wiernych. Dekanat wrocławski w 1930 roku był największy w całej diecezji. Miał 24 placówki duszpasterskie. ${ }^{128}$ Ze względu na wielkość, dekretem kardynała Bertrama z dnia 11 stycznia 1931 roku zostal podzielony na dekanat: Wroclaw-Pólnoc i Wrockaw-Południe. Dekanat Wrocław-Pólnoc obejmowal następujące placówwki duszpasterskie:
1. Sw. Bonifacego
8. Sw. Piatra Kanizego
2. Sw. Jadwigi
9. Sw. Rodziny
3. Sw. Krzyża
10. Sw. Wincentego
4. Sw. Macieja
11. Sw. Wojciecha
5. Najśw. Marii Panny
12. Wrocław-Karlowice
6. Sw. Michała
13. Wroclaw-Csoborwice

7. Sw. Miikołaja

Dekanat Wnocław-Południe stanowiły niżej podane placówki duszpasterskie:

1. Bożego Ciała

2. Sw. Donoty

3. Sw. Elizhiety

4. Sw. Henryika

5. Sw. Karola

6. Sw. Klemensa Hofbauera
7. Sw. Maurycego

8. Trójcy Przenajświętszej

9. Brochów

10. Muchobór Wielki

11. Wrocław-Ciążyn

Oba dekanaty $w$ dalszym ciąsu należeć miały do komisariatu wrocławskiego. Dla zachowania jeänolitego kierunku duszpasterskiego, kierownictwo aikcji katolickiej i centralnej kartoteki parafialnej pozostało jedno dla całego Wrockawia. Wrocławski komisarz biskupi występowal

120 Kirchl. Amtsbl., 9 (1926), s. 69.

121 Handbuch... 1918, dz. c., s. 37 ns.

122 Tamże, s. 58 ns.

123 Real-Handbuch..., dz. c., cz. 2, s. 330 .

124 Verordnungen..., 13 (1925), s. 69.

125 Tamże, 16 (1925), s. 88.

126 Handbuch des Bistums Breslau für das Jahr 1930, s. 33 ns. 
w dalszym ciągu jakso „najwyższy praboszcz" tego akręgu. Zarządzenie kardynała weszłło $\mathrm{w}$ życie $1 \mathrm{kwiésnia} 1931$ roku. ${ }^{127}$

W tym samym roku został podzielony dekanat gliwicki liczący 18 placówek duszpasterskich. Dekret z dnia 25 października 1931 roku jako racje podziału podaje znaczną liczbę wiernych i placówek duszpasterskich, oraz nadmiar obowiązków, którym trudno sprostać jednemu dziekanowi. Z wydzielonej części powstał nowy dekanat Łabędy obejmujący parafie:
1. Bojkow
6. Rachowice
2. Brzeźnica
7. Rudy Racuiborskie
3. Łabędy
8. Sośnicowice
4. Ostropa
9. Żernica
5. Pilchowice

W dekanacie gliwickim pozostały następujące placówki duszpasterskie połozione na terenie Gliwic:

1. parafia Sw. Antoniego Gliwice-Wójtowa Wieś

2. parafia Sw. Bartłomieja

3. kuracja Sw. Jana

4. kuracja Sw. Józefa

5. parafia Najśw. Marii Panny Gliwice-Sośnica

6. parafia Sw. Piotra i Pawła

7. kuracja Sw. Rodziny

8. kuracja Najshodszego Serea Jezusowego

9. parafia Wszystkich Swiętych. 123

Dekanat bytomski obejmował miasto i okoliczne parafie. W 1937 roku z parafii i kuracji polożonych poza mjastem stworzono nowy dekanat Miechowice, do którego przydzielono:

1. parafie Dabrego Pasterza w Bobrku

2. parafię Sw. Rodziny w Bobrku

3. parafię Bożego Ciała w Miechowicach

4. parafię Sw. Krzyża w Miechowicach

5. parafię Rokitnica

6. parafię Szombierki

7. kurację Stolarzowice'

$\mathrm{W}$ dekanacie bytomskcim pozostały:

1. parafia Sw. Barbary

2. parafia Sw. Jacka

3. kuracja Sw. Jozefa

${ }^{127}$ Teilung des Archipresbyterats Breslau in die beiden Archipresibyterate Breslau-Nord und Breslau-Süd, dekret z dn. 11. 1. 1931 r., W: Kirchl. Amtsbl., 3 (1931), s. 11.

${ }^{128}$ Teilung des Archipresbyterats Gleiwitz in die beiden Archipresbyterate Gleiwitz und Laband, dekret $\mathrm{z}$ dn. 25. 10. 1931 r., W: Kirchl. Amtsbl., 18 (1931), s. 139. 
4. kuracja Sw. Krzyża

5. parafia Najśw. Marii Panny

6. kuracja Najsłodszego Serca Jezusowego

7. parafia Trójcy Przenajświętszej. ${ }^{129}$

Dekanat Gorzów Wielkapolski powstał na początku 1940 noku z dekanatu Neuzelle, który obejmował 17.173 wiernych należących do piętnastu placówek duszpasterskich położonych w ośmiu powiatach. ${ }^{130}$ Mieszkańców na tym terenie było ponad pół miliona. ${ }^{131}$ Do podziału tego dekanatu skłoniła kardynała rozległość terytorium. W nowym uformowaniu dekanat Neuzelle składał się z placówek duszpasterskich:

1. Fünsterberg

4. Lubsko

2. Gubin

5. Neuzelle

3. Krosno Odrzańskie

6. Żytowań

Do nowoerygowanego dekanatu Gorzów Wielkopolski przydzielono:

1. Beeskow

2. Dębno

3. Drezdenko

4. Gorzów Wpl. par. Sw. Józefa

5. Gorzów Wpl. par. Sw. Krzyża
6. Kostrzyn

7. Myślibórz

8. Strzelce Krajeńskie

9. Sulęcin. ${ }^{132}$

Ostatnie dekanaty, które erygowal kardynał Bertram w 1944 roku, to Zagwiździe i Groszowice. Dekanat Zagwiździe powolano do życia dnia 1 czerwca 1944 roku z racji dużej liczby placówek duszpasterskich w dekanacie Siołkowice. Przydzielono do niego następujące placówki duszpasterskie:

z dekanatu siołkowskiego:

1. Bierdzany

4. Jelowa

2. Dąbrówka Dolna

5. Stare Budkowice

3. Fałkowice

6. Zagwiździe

z dekanatu opolskiego:

7. Katórz Wielki

8. Ligota Turawska

9. Osowiec-Węgry

z dekanatu kluczborskiego:

10. Tuly

129 Teilung des Archipresbyterats Beuthen O/S. in die beiden Archipresbyterate Beuthen und Mechtal, dekret $z$ dn. 24. 10. 1937 r., W: Kirchl. Amtsbl., 18 (1937), s. 148.

130 Handbuch... 1940, dz. c., S. 55 ns.

181 M o h n e n J., dz. c., s. 306.

132 Teilung des Archipresbyterats Neuzelle in die beiden Archipresbyterat Neuzelle und Landsberg a. W., dekret $z$ stycznia $1940 \mathrm{r}$., W: Kirchl. Amtsbl., 4 (1940), s. 26 ns. (Podzial nastąpił z dniem 1. 2. 1940 r., a data podana na Ubersichtskarte W: Atlas des Erzbistums Breslau, dz. c., jest dniem ogłoszenia w điecezjalnym piśmie urzędowym). 
z dekanatu namysłowskiego:

11. Pokój. ${ }^{183}$

Erygowany dekanat zająl wschodnią część bardzo niekształtnego terytorium dekanatu Siolkowice. ${ }^{134}$

Dekanat Groszowice powstal dnia 27 września 1944 roku z padziału dekanatu Opole, który mimo wyłączenia trzech placówek duszpasterskich i włączenie do dekanatu Zagwoździe obejmował jeszcze 12 parafii, 4 kuracje i 1 lokalię.

Kardynał Bertram obok dużej ilości placówek duszpasterskich wziął pad uwage rozległośc terytorium i liczbe wiernych przekraczającą 80.000. ${ }^{135}$ Do dekanatu Groszowice weszly:

1. parafia Chrząstowice (Chrząsty)

6. kuracja Ozimek

2. parafia Dębie

7. parafia Raszawa

3. lokalia Dylaki

8. parafia Szczedrzyk

4. parafia Groszorwice

9. paraflia Tarnów Opolski

5. kuracja Krosnica

Nowoerygowany dekanat pozostał w komisariacie opolskrim. ${ }^{136}$

Obok zmian dotyczących całych dekanatów, dokonano kilka przesunięć paszczególnych parafiji do sąsiedniego dekanatu, aby dziekanowi ułatwić pracę, a proboszczowi i wiernym dostęp do urzędu dziekańskiego. Paraflę Bystrzyca Gónna w 1919 roku wyłączono z dekanatu wałbrzyskiego, przydzielając do dekanatu kielczyńskiego (świdnickiego). ${ }^{187}$ Kurację Rothenburg (Lausitz) - Czerwińsk Eużycki wyłączono z dekanatu żarskiego i wcielono w 1926 roku do diekanatu lubańskiego. ${ }^{138}$ W 1927 roku przeniesiono parafię Sośnica z dekanatu zabrzańskiego ${ }^{139}$ do gliwickiego ${ }^{140}$ ì parafię Zawada Książęca $z$ deukanatu kozielskiego do raciborskiego. ${ }^{141}$ Stworzoną dnila 1 listopada 1927 noku kurację Kąty włączono do dekanatu prószkowskiego. W następstwie tego przesunięta granica dekanatu prószkowskiego abjęła $z$ dekanatu apolskiego wieś Przywary wydzieloną $z$ parafiji Groszowice i z dekanatu strzeleckiego wies Charuła wydzieloną z parafii Otmęt. ${ }^{142}$ Kurację Zawiść z dekanatu siołkowskiego przydzielono w 1930 roku do klucz-

${ }^{133}$ Teilung des Archipresbyterats Schalkenidorf und Bildung eines Archipresbyterats Friedrichstal, W: Kirchl. Amtsbl..., 11 (1944) s. 63.

184 Atlas..., dz. c., mapa nr 451, 452.

195 Handbuch... 1942, s. 76 ns.

196 Anordnung betreffend die Teilung des Archipresbyterates Oppein und Bildung des Archipresbyterates Groschowitz, W: Kirchl. Amtsbl..., 20 (1944), s. 110.

187 Verordnungen.., 4 (1919), s. 32.

158 Kirchl. Amtsbl., 7 (1927), s. 57.

199 Handbuch... 1918, dz. c., s. 50.

$140 \mathrm{Kirchl}$. Amtsbl., 4 (1927), s. 21.

141 Tamże, 14 (1927), s. 86.

142 Tamże, 19 (1927), s. 109. 
borskiego. ${ }^{143}$ Parafię Karlowice Brzeskie z dekanatu brzeskiego wlączono w 1937 roku do siolkowskiego. ${ }^{141}$ Pismem z dnia 2 Iistopada 1938 roku parafię Wierzch $z$ dekanatu Biała przeniesiono do dekanatu Głogówek, z mocą abowiązującą od dnia 1 stycznia 1939 roku. ${ }^{145}$ Znaczne przesunięcia granic nastapiły dnia 1 czerwca 1944 roku z racji stworzenia dekanatu Zagwiździe, do którego obok 6 parafii z macierzystego dekanatu siokkowskiego weszło 3 parafie $\mathrm{z}$ dekanatu opolskiego, 1 $\mathrm{z}$ dekanatu kluczborskiego i $1 \mathrm{z}$ dekanatu namysłowskiego. ${ }^{146}$

Dla ułatwienia administracji, kardynal Bertram z dniem 1 lipca 1938 roku zniósł dekanat Nowogrodziec. Parafię Mściszów i Uniegoszcz leżące na przedmieściach Lubania włączono do dekanatu Lubań, parafie Brzeźnilk (odl. $8 \mathrm{~km}$. ad Bolesławca) i Nowogradziec do dekanatu Bolesławiec, a parafię Kotliska do dekanatu Wleń. ${ }^{147}$ Ogólne akta dekanatu przeniesiono do Bolesławca.

W komisariacie cieszyńskim erygowano 1927 roku dekanat Sląska Ostrawa stworzony $z$ podziału dekanatu Karwina, w którym pozostawiono parafie:
1. Błędowice
5. Orlowa
2. Karwina
6. Stanowa
3. Sucha Srednia
7. Cierlicko
4. Sucha Góra

Nastepujące parafie weszły $w$ skład dekanatu Sląska Ostrawa:
1. Hermanice
5. Peterswald
2. Hruszów,
6. Radwanice
3. Michałkowice
7. Szonów
4. Ostrawa Sląska
8. Wracimowice. ${ }^{148}$

Rozwój życia katolickiego i kościelnej organizacji w delegaturze berlińskiej był przyczyną nowego podziału terytorium. Kardynał Bertram dnia 8 kwietnia 1924 roku z dziewięciu stworzył trzynaście dekanatów, w skład których wchodziło ad pięciu do dwunastu parafii. Dziesięć dekanatów polożonych było w Brandenburgii:
1. Berlin-Zachód
6. Oberschönwalde
2. Berlin-Wschód
7. Poczdam
3. Charlottenburg
8. Reinickendorf,
4. Frankfurt n/O.
9. Steglitz
5. Neukölln
10. Wittenberge

\footnotetext{
143 Tamże, 6 (1937), s. 106.

144 Tamże, 6 (1937), s. 53.

145 Tamże, 4 (1939), s. 30.

${ }_{146}$ Teilung des Archipresbyterats Schalkendorf..., dekret c., W: Kirchl. Amtsbl., 11 (1944), s. 63.

${ }_{147}$ Aufteilung des Archipresibyterats Naumburg a. Queis, dekret $z \mathrm{dn}$. 11. 6. 1938 r., W: Kirchl. Amtsbl., 10 (1938), s. 70.

148 Real-Handbuch..., dz. c., cz. 2, s. 417.
} 
Na trzy dekanaty podzielone było Pomorze:

1. Koszalin

2. Stralsund

3. Szczecin. ${ }^{149}$

Wymienione dekanaty przetrwały $w$ tej liczbie nie tylko do czasu erekcji ibisikupstwa berlińskiego, ${ }^{150}$, ale przez wiele następnych lat. ${ }^{131}$

Diecezja wrockawska w 1945 roku podzielona była na 89 dekanatów, z których 87 podlegało bezpośrednio jurysdykcji kardynała Bertrama, a 2 oddane były $w$ zarząd arcybiskupowi Olomunca, który posiadał nad nimi władzę delegowaną, jaki biskupi administrator.

\section{Zakończenie}

Czas od 1914 do 1945 roku to okres wielkich wydarzeń i przemian politycznych w Niemczech, w Europie i w całym świecie. Czynniki te stanowily zewnętrzną przyczynę zmiany granic i pociągnęly za soba nowe ukształtowanie jednostek administracyjnych diecezji wrocławskiej. Wewnętrznymi przyczynami specyficznego podziału terytorialnego i powstania charakterystycznych dla diecezji wrocławskiej instytucji prawnych to: protestantyzm, rozległość diecezji, położenie części diecezji poza granicami państwa niemieokiego i wierni używający języka niemieckiego, polskiego i czeskiego. Kościół wypracowywał w ciągu wieków coraz to lepszą organizacje terytorialną. Kodeks Prawa Kanonicznego przyjął te formy jako sprawdzone doświadczeniem. Kardynał Bertram utrzymywał i erygował dla duchowego pożytku wiernych nie tylko liczne komisariaty biskupie, dekanaty i parafie, ale kuracje niezależne, kuracje zależne (lokalie), kościoły „mater adiuncta”, kościoly filialne, kaplice publiczne i punkty duszpasterskie (Gottesdienstation), które mieściły się $w$ szkołach, ewentualnie $w$ budynkach państwowych lub prywatnych. Diecezja wroclawska w omawianych latach liczyla ponad 700 parafii, a w ciągu rządów kardynała Bertrama poczyniono ponad 200 przesunięć granicznych między parafiami. Prawo kościelne ma przede wszystkim charakter terytorialny. Przez określenie granic diecezji wroclawskiej oraz wchodzących $w$ jej skład komisariatów biskupich i dekanatów ukazano przestrzenny zasięg jurysdykcji biskupa tej diecezji, oraz uprawnień komisarzy i dziekanów.

149 Neuteilung der Archipresbyterate des Delegaturbezirks, dekret $\mathrm{z}$ dn. 8. 4. 1924 r., W: Verordnungen..., 7 (1924), s. $47 \mathrm{~ns}$.

150 Sauren J., Kirchliche Statistik Deutschlands, Kirchl. Handb., t. 16 (1928-1929), s. 178 .

$151 \mathrm{M}$ ohn en J., dz. c., s. 304 . 
Die Grenzen und die Teilung der Diözese Breslau an die Kommissariate und Archipresbyterate in Jahren 1914-1945

\section{ZUSAMMENFASSUNG}

Die Diözese Breslau ist im Jahre 1000 gegründet worden. Das Territorium des Bistums war immer mit dem Schlesierland gebundet. Am 23. 4. 1155 hat es der Papst Hedrian IV unter seinen Schutz genommen. Die päpstliche Urkunde zählt die angehörigen Burgenbezirke auf, und zeigt uns den Umfang des Diözesansprengels in dieser Zeit. Nach 90 Jahren stellte Papst Innozenz IV die neue Schutzurkunde für das Bistum Breslau aus. Die Grenzen wurden im Laufe der Jahrhunderte vielfach geändert. Im Jahre 1914 wurde es die grösste Diözese Deutschlands, und dehnte sich im allgemeinen von den Beskiden bis an die Meeresküste aus. Im Grunde genommen fasste die Diözese damals das Land Schlesien (mit einer Ausnahme des Leobschützer Landes, der Grafschaft Glatz und der Lausitz) und die Provinzen Brandenburg und Pommern. Im Erfolg des ersten Weltkrieges für den an Polen gefallenen Teil Oberschlesiens richtete Card. Bertram eine Fürstbischöfliche Delegatur ein. Am 31.11.1922 emannte der Papst eine Apostolische Administratur, die durch das Konkordat des Hl. Stuhles mit der Republik Polen vom 10.11.1925 zur Diözese Kattowitz erhoben war und als Suffraganbistum dem Erzbistum Krakau unterstellt worden ist. In Niederschlesien wurden 7 Pfarreien dem polnischen Staatsgebiet zuteil. Der Fürstbischof von Breslau behielt die Jurisdiktion über sie, bis das Konksordat dieses Gebiet mit der Erzdiözese Gnesen-Posen vereinigte. Im Teil des Bistums Breslau (Westschlesien und Ostschlesien), der nach dem ersten Weltkriege der Tschechoslowakei zuteilt wurde, übte der Cardinal Bertram die Jurisdiktion durch die fürstbischöflichen Kommissare, die das Recht eines Generalvikars hatten, aus. Durch das Konkordat, welches die preussische Regierung am 14.6.1929 mit Hl. Stuhle geschlossen hat, wurde die Delegatur Brandenburg - Pommern von Breslau abgetrennt und man bildete aus ihr die Diözese Berlin. Die Diözese Breslau dagegen ist zur Erzdiözese erhoben worden. Ihr sind auch als Suffragane die Diözesen: Berlin, Ermland und die Apostolische Administratur Schneidemühl untergeordnet.

Die ganze Diözese wurde in 3 Verwaltungsbezirke eingeteillt: preussischer Anteil, tschechoslowakischer Anteil und Delegatur für die Mark Brandenburg und Pommern. Jeder Teil war in Kommissariate gegliedert. Die Hauptaufgabe der fürstbischöflichen Kommissare war die Visitation der Erzpriester, Ausführung besonderer Mandate des Ordinariats. Ordnung des amtlichen Nachlasses der Erzpriester beim erfolgiten Ableben dersleben. Die Kommissariate wurden in Archipresbyterate gegliedert, an deren Spitze in Erzpriester stand. Die Grenzen der Archipresbyterate wurden in Jahren 1914-1945 vielfach geändert. 